Special Issue on "The Adrenal Gland: Development, Function and Tissue Maintenance".

\title{
The Invention of Aldosterone, How the Past Resurfaces in Pediatric Endocrinology
}

Say Viengchareun ${ }^{1}$, Eric Pussard ${ }^{1,2}$, Mireille Castanet $^{3}$, Laurent M. Sachs ${ }^{4}$, Thi An Vu ${ }^{1}$, Pascal Boileau ${ }^{1,5}$, Marc Lombès ${ }^{1}$, Laetitia Martinerie ${ }^{1,6}$.

${ }^{1}$ Université Paris-Saclay, Inserm, Physiologie et Physiopathologie Endocriniennes, 94276, Le Kremlin-Bicêtre, France;

${ }^{2}$ Service de Génétique Moléculaire, Pharmacogénétique et Hormonologie, Hôpital de Bicêtre, Assistance Publique-Hôpitaux de Paris, 94275, Le Kremlin Bicêtre, France;

${ }^{3}$ Normandie Univ, UNIROUEN, Inserm U1239, CHU Rouen, Department of pediatrics, F-76000 Rouen, France;

${ }^{4}$ UMR 7221 Molecular Physiology and Adaption, Department Adaptation of Life, Centre National de la Recherche Scientifique, Muséum National d'Histoire Naturelle, Paris, France;

${ }^{5}$ Department of Neonatal Pediatrics, Centre Hospitalier Intercommunal de Poissy-Saint-Germain, 10, rue du champ Gaillard, 78300 Poissy, France; Université Paris-Saclay, UVSQ, 78180, Montigny-Le-Bretonneux, France ;

${ }^{6}$ Pediatric Endocrinology Department, Hôpital Universitaire Robert-Debre, 75019, Paris, France \& Université de Paris, 75019, Paris, France.

\section{Corresponding author}

Laetitia Martinerie, $\mathrm{MD}, \mathrm{PhD}$

Inserm U1185

63, rue Gabriel Péri

94276 Le Kremlin Bicêtre Cedex

laetitia.martinerie@aphp.fr

Short title: Aldosterone and the conquest of land

Key words: Aldosterone, mineralocorticoid receptor, neonates, human, amphibian, fish

Conflict of Interest: The authors declare that there is no conflict of interest that could be perceived as prejudicing the impartiality of the research.

Funding: This research was supported by grants from the French National Institute for Health and Medical Research (Inserm), the University Paris-Saclay, and the French National Agency for Research (ANR), grant no. ANR-20-CE14-0015 (PERIMIRE). 


\begin{abstract}
Sodium and water homeostasis are drastically modified at birth, in mammals, by the transition from aquatic life to terrestrial life. Accumulating evidence during the past ten years underscores the central role for the mineralocorticoid signaling pathway, in the fine regulation of this equilibrium, at this critical period of development. Interestingly, regarding evolution, while the mineralocorticoid receptor is expressed in fish, the appearance of its related ligand, aldosterone, coincides with terrestrial life, as it is first detected in lungfish and amphibian. Thus, aldosterone is likely the main hormone regulating the transition from an aquatic environment to an air environment. This review will focus on the different actors of the mineralocorticoid signaling pathway from aldosterone secretion in the adrenal gland, to mineralocorticoid receptor expression in the kidney, summarizing their regulation and roles throughout fetal and neonatal development, in the light of evolution.
\end{abstract}




\section{Introduction}

Sodium and water homeostasis are finely regulated by the mineralocorticoid signaling pathway, notably in the distal nephron in mammals. However, this equilibrium is challenged at birth by the transition from intrauterine to extrauterine life. Accumulating evidence suggests that aldosterone may be one of the key regulators for this transition. This review will emphasize the regulation and role of the mineralocorticoid signaling pathway (mainly aldosterone and its receptor, the mineralocorticoid receptor), throughout fetal and neonatal development, in the light of evolution.

\section{Sodium and Water Homeostasis and Special Features in Full-term and Preterm Newborns}

Sodium and water homeostasis constitute the physiological processes regulating the stability of plasma osmolarity and plasma volume. Water is divided in the body into three compartments: the intracellular compartment, and the interstitial and plasma compartments that both form the extracellular compartment. The body water content depends on the water stock, but its distribution among the different compartments relies mainly on sodium balance. In humans, sodium balance is regulated by two variables: food inputs, and outputs (renal in majority, and extrarenal in minority, under physiological conditions). The efficiency of renal control of sodium and water balance is based on an equilibrium between the filtered sodium flow (dependent on serum sodium and glomerular filtration rate) and tubular reabsorption of sodium (Devuyst, 2008). The latter is made possible by the joint and coordinated intervention of the different segments of the nephron, contributing to the reabsorption of $99 \%$ of the ultrafiltered sodium. The distal parts of the nephron (distal convoluted tubule, connecting duct and collecting duct) are involved in the fine regulation of sodium balance (Palmer and Schnermann, 2015). The effectors of this regulation act in response to stimulation of baroreceptors and 
voloreceptors; these are various neuroendocrine systems including the renin-angiotensinaldosterone system (RAAS), the atrial natriuretic factor, vegetative innervation, or the prostaglandin system. Segments of the nephron expressing the mineralocorticoid receptor (MR) are grouped together under the term Aldosterone Sensitive Distal Nephron (ASDN). The epithelium of the collecting duct is made up of tight intercellular junctions (desmosomes) preventing any extracellular transport. Transcellular sodium reabsorption therefore involves two main transporters: the Epithelial $\mathrm{Na}^{+}$Channel $(\mathrm{ENaC})$ and the $\mathrm{Na}^{+} / \mathrm{K}^{+}$-ATPase pump. In addition, the principal cells of the collecting duct are also the site of transepithelial water reabsorption thanks to the osmotic force induced by sodium transport. This water reabsorption is mostly ensured by the aquaporic channels: AQP2, expression of which is located at the apical membrane, is induced by vasopressin and also regulated by aldosterone (Hasler et al., 2003) while AQP3 and AQP4 are constitutively expressed at the basolateral membrane. The collecting duct therefore appears to be the site of the final modulation of renal sodium and water reabsorption.

In utero, sodium and water homeostasis are initially regulated in the fetus by the placenta. Kidneys only play an ancillary role, since the absence of a kidney is compatible with a live born infant at full-term (anephric newborn) (Gunn et al., 1988). Glomerular filtration and emission of the first urine begin at the $10^{\text {th }}$ gestational week $(\mathrm{GW})$ contributing to the production of amniotic fluid. The amount of amniotic fluid increases from $25 \mathrm{ml}$ at $10 \mathrm{GW}$ to $400 \mathrm{ml}$ at $20 \mathrm{GW}$, with a composition similar to that of the fetal plasma. Indeed, prior to skin keratinization, water and solutes diffuse freely between spaces, in a bidirectional manner. The amniotic fluid then serves as a physiological buffer and corresponds to an extension of the extracellular environment of the fetus. Fetal keratinization begins around $14 \mathrm{GW}$ with a phase of follicular keratinization, then continues with a phase of interfollicular keratinization which usually ends at the $25^{\text {th }} \mathrm{GW}$. After this phase of keratinization, the volume and composition of 
the amniotic fluid become dependent on several levels of regulation (renal production, swallowing of the fetus, oral, esophageal and pulmonary fluids of the fetus, inter and transmembrane transfers), and are then submitted to active exchanges between the different compartments (Underwood et al., 2005). Thus, along with the development of the various functions of the kidneys, composition of the amniotic fluid evolves. Sodium and chlorine concentrations decrease from the second trimester of pregnancy, while urea and creatinine concentrations increase. The overall osmolality of amniotic fluid decreases (Underwood et al., 2005). Around $36 \mathrm{GW}$, nephrogenesis (formation of new nephrons) is complete, and the kidneys, although still immature, can take over the regulation of sodium and water balance in the fetus.

At birth and in the postnatal period, renal function must adapt to the delicate task of establishing an effective purification function while ensuring the fluid-electrolyte balance. The immaturity of the main renal functions (glomerular and tubular) in the newborn, the disruption of the composition of the internal environment by the physiological changes of transition between the intrauterine aquatic environment and the extrauterine terrestrial environment, and the need to adapt to the requirements of rapid growth, make this phase of adaptation all the more complex. Growth requires the establishment of a positive hydro-electrolyte balance, with inputs greater than outputs. As part of the adjustment to extrauterine life, other important changes are added during the neonatal period. The physiological weight loss observed during the neonatal period (usually up to $5-10 \%$ of the body weight) occurs mainly to the detriment of the extracellular compartment and more particularly the interstitial compartment (the vascular compartment remaining stable, of the order of 5\% from birth, as in adults). The urine output of full-term newborns is between 1 and $3 \mathrm{ml} / \mathrm{kg} / \mathrm{h}$. The reduction of extracellular volume may reach $15 \%$ of body weight in premature infants and is associated with a urine output of up to $7 \mathrm{ml} / \mathrm{kg} / \mathrm{h}$ (Lindower, 2017; Suarez-Rivera and Bonilla-Felix, 2014). Glomerular filtration 
increases sharply during the first hours of life, however, remains low $\left(20 \mathrm{ml} / \mathrm{min} / 1.73 \mathrm{~m}^{2}\right)$. It is multiplied by 2 on the $15^{\text {th }}$ day of life, then increases more gradually to reach levels close to that of adults at the age of 1 year. The glomerular filtration rate is even lower in very premature infants, around $10 \mathrm{ml} / \mathrm{min} / 1.73 \mathrm{~m}^{2}$ at birth (Bockenhauer and Zieg, 2014). This partially explains the slow elimination of maternal plasma creatinine levels, which takes only a few days in the full-term newborn, and can reach several weeks in the very premature infant (van den Anker et al., 1995). The mechanism of concentration/dilution of urine is essential to regulate water balance. This mainly relies on the action of vasopressin or antidiuretic hormone. In newborns, urine osmolality is lower, in the order of $600 \mathrm{mOsm} / \mathrm{kg}$, or even $500 \mathrm{mOsm} / \mathrm{kg}$ in premature babies. The capacity to concentrate urine increases gradually and reaches adult levels around the age of 1 year (Suarez-Rivera and Bonilla-Felix, 2014). Conversely, the power of urine dilution is acquired in utero, and does not differ between premature infants, full-term newborns and adults. Under normal physiological conditions, the kidneys of the full-term newborns must excrete the fluid overload acquired during fetal life (Lindower, 2017). Therefore, the ability to concentrate urine is not necessary at birth. However, in premature infants, whose fluid overload is greater and the power of urine concentration weaker, the risk of hydro-electrolyte disorders becomes significant (Bockenhauer and Zieg, 2014; SuarezRivera and Bonilla-Felix, 2014).

Renal control of sodium excretion is essential for maintaining blood volume and a positive sodium balance, crucial for normal growth. The fraction of excreted sodium is high at birth but decreases rapidly in full-term newborns and reaches less than 1\% (Suarez-Rivera and BonillaFelix, 2014). In premature infants, this adaptation takes place more slowly, over 2 to 3 weeks, especially before $34 \mathrm{GW}$, where the fraction of excreted sodium can reach 3 to $5 \%$ and often requires systematic sodium supplementation (Suarez-Rivera and Bonilla-Felix, 2014). The fullterm newborn retains about $30 \%$ of the sodium ingested, however cannot excrete excess sodium 
or water load. This ability is not acquired until the end of the first year of life (Zoetis and Hurtt, 2003). All of these maturation processes of renal function are integrated with the development of the different structures of the kidney (Zoetis and Hurtt, 2003) and the progressive expression of the different players (hormone receptors, ion channels and transporters) of the regulation of sodium and water balance, in particular of the mineralocorticoid signaling pathway.

\section{The Mineralocorticoid Signaling Pathway}

The first step in the activation of the mineralocorticoid signaling pathway is characterized by the biosynthesis and secretion of the steroid hormone aldosterone, which is the predominant mineralocorticoid hormone in mammals. This hormone is synthesized in the zona glomerulosa (ZG) of the adrenal cortex.

\subsection{Aldosterone Biosynthesis, Secretion, and Regulation}

The pathway of human aldosterone biosynthesis by the ZG is now well understood. The ZG is the outermost layer of the adrenal cortex, lying just beneath the fibrous capsule and composed of clustered cells that uniquely express aldosterone synthase (CYP11B2), the steroidogenic enzyme encoded by the $C Y P 11 B 2$ gene that performs the final stages of aldosterone production. Beneath the $\mathrm{ZG}$, lies the zona fasciculata $(\mathrm{ZF})$, and, underneath, the zona reticularis $(\mathrm{ZR})$, which produces glucocorticoids and adrenal androgens, respectively (Seccia et al., 2018).

The first step in steroidogenesis takes place within mitochondria that contains very little cholesterol. The steroidogenic acute regulatory protein, StAR (encoded by the STAR gene) ensures cholesterol import from the outer to the inner mitochondrial membrane. This mitochondrial translocation is the rate-limiting step in steroidogenesis. Then, the mitochondrial enzyme, cytochrome P450scc (encoded by the CYP11A1 gene) cleaves cholesterol sidechain to produce pregnenolone. Subsequent conversion of pregnenolone to progesterone is catalyzed by the type $23 \beta$-hydroxysteroid dehydrogenase/d $\Delta 5-\Delta 4$ isomerase, encoded by the $H S D 3 B 2$ gene 
and located in the membrane of the endoplasmic reticulum. As the adrenal ZG does not express P450c17, progesterone is 21-hydroxylated into 11-deoxycorticosterone (DOC) by the microsomal P450c21 encoded by the CYP21A2 gene. The restricted expression of aldosterone synthase (P450c11AS encoded by the CYP11B2 gene, located at 8q22 in humans, and comprising 9 exons and over 7000 base pairs (Bassett et al., 2004) ensures zonal control of aldosterone secretion in ZG. CYP11B2 gene locates in tandem with the highly homologous CYP11B1 gene, which encodes the 11ß-hydroxylase enzyme essential to cortisol synthesis in ZF. Nevertheless, CYP11B1 gene and CYP11B2 are never commonly coexpressed and P450c11AS sequentially catalyzes 11-hydroxylase, 18-hydroxylase and 18-methyl oxidase activities in ZG, yielding successively to corticosterone, 18-hydroxycorticosterone and finally aldosterone (Miller and Auchus, 2011).

As the adrenal ZG has no capacity to store aldosterone once it is produced, the regulation of the secretion is inextricably linked to transcriptional activation as well as posttranscriptional modification of steroidogenic enzymes. Acute aldosterone production is controlled by the early regulatory step of cholesterol uptake and conversion to pregnenolone that is mediated by increased expression and phosphorylation of StAR. A late regulatory step controlling the expression of biosynthesis enzymes, particularly CYP11B2, regulates chronic aldosterone production. Aldosterone biosynthesis in the ZG is physiologically regulated by angiotensin II (Ang II), potassium $\left(\mathrm{K}^{+}\right)$, and at a lesser extent by the adrenocorticotropic hormone (ACTH). Membrane depolarization and increase in intracellular calcium levels are the most important determinants of aldosterone secretion (Figure 1). The renin-angiotensin-aldosterone system (RAAS) is initiated by various stimuli such as increased sympathetic activity, reduced perfusion pressure in the renal afferent arterioles or decreased sodium content facing the macula densa of the renal distal tubules that release renin from juxtaglomerular cells. Afterward, renin converts angiotensinogen to angiotensin I, which is subsequently cleaved by Angiotensin Converting 
Enzyme (ACE) to form the octapeptide Ang II. Binding of Ang II to its AT1 receptor activates phospholipase $\mathrm{C}$, and, thus, triggers an InsP3-dependent release of calcium from intracellular stores. A sustained aldosterone secretion induced by Ang II requires additional calcium entry from membrane calcium channels. The raised cytoplasmic calcium concentration in the ZG activates calcium/calmodulin-dependent protein kinases (CaMKs), which increase expression and phosphorylation of transcription factors such as Nur-related factor 1 (Nurr1), nerve growth factor-induced clone B (NGFIB), Activating transcription factor 1 (ATF1), and CAMP responsive element binding protein 1 (CREB1). These transcription factors in turn activate promoter sites of $C Y P 11 B 2$ and StAR transcription and increase aldosterone. The higher demand for cholesterol requires its uptake from plasma lipoproteins. Ang II increases the expression of LDL and HDL receptors, which improves cholesterol availability for steroidogenesis. Ang II also activates the cellular hormone-sensitive lipase to release cholesterol stored in esterified form in lipid droplets (MacKenzie et al., 2019). Circulating potassium is also one of the major regulators of aldosterone secretion in ZG cells. Adrenal glomerulosa cells exhibit a high background potassium membrane conductance. Small increases in extracellular potassium depolarize the glomerulosa cells, increasing calcium influx through voltage-gated calcium channels that stimulates $C Y P 11 B 2$ and StAR transcription (Hattangady et al., 2012). Therefore, multiple potassium and calcium channels regulate aldosterone secretion. ZG potassium channels as well as $\mathrm{Na}^{+}-\mathrm{K}^{+}$-ATPase control the repolarization of the cell membrane following calcium influx; any alteration of cell repolarization extends the time of calcium channels opening and therefore lengthens the duration of aldosterone secretion. Several mutations affecting ion channels and pumps have been reported to be associated with hormone overproduction in autonomous aldosteroneproducing adenomas (Beuschlein et al., 2013; Choi et al., 2011; Fernandes-Rosa et al., 2018; Nakamura et al., 2015; Scholl et al., 2018, 2015, 2013; Zennaro et al., 2020, 2017). 
ACTH only stimulates aldosterone secretion acutely and transiently, but to a lesser extent than Ang II and $\mathrm{K}^{+}$. ACTH binds to the transmembrane receptor melanocortin receptor 2 expressed both in ZG and ZF cells and exerts its downstream effects by activating adenylate cyclase, thus stimulating StAR expression (Betancourt-Calle et al., 2001). Aldosterone production is also regulated through a paracrine mechanism by bioactive compounds (leptin, serotonin, catecholamines, atrial natriuretic peptide, endothelin, nitric oxide, neuropeptide substance P) released by various cells such as adipocytes, mast cells, chromaffin cells or nerve ending located in the vicinity of adrenocortical ZG cells (Lefebvre et al., 2019; Wils et al., 2020). Finally, some studies have shown that numerous miRNAs regulate aldosterone production though posttranscriptional regulation of CYP11B2 or StAR expressions (Robertson et al., 2017).

\subsection{The Mineralocorticoid Receptor}

\subsubsection{Gene structure and functional domains}

The genomic effects of aldosterone are mediated by the Mineralocorticoid Receptor (MR), a nuclear receptor acting as a transcription factor capable of modulating expression of target genes responsible for physiological effects of aldosterone (Viengchareun et al., 2007). The $N R 3 C 2$ gene, encoding the human MR, extends over nearly $450 \mathrm{~kb}$ and is located at locus 4q31.1-4q31.2 (Fan et al., 1989; Morrison et al., 1990). The $h M R$ gene presents with 10 exons and 8 introns: the first two exons, $1 \alpha$ and $1 \beta$, are not translated and are spliced alternatively onto the common exon 2, generating two messenger isoforms (hMR $\alpha$ and hMR $\beta$ ), which encode the same 984 amino-acids protein ( 107 kDa) (Zennaro et al., 1995). MR protein is organized into four distinct structural domains, including the N-terminal domain (NTD), the DNA binding domain (DBD), the hinge region and the ligand binding domain (LBD). 


\subsubsection{MR Expression in Epithelial and Non-epithelial Tissues}

MR expression was first described in epithelial tissues, in which MR and aldosterone stimulate sodium reabsorption and excretion of potassium (Bonvalet, 1998; Marver et al., 1974). Its expression was demonstrated in the kidney, first in the distal convoluted tubules and cortical collecting ducts (Krozowski et al., 1989; Lombès et al., 1990) and later, in the mesangial cells (Miyata et al., 2005; Nishiyama et al., 2005) and podocytes of the glomeruli (Shibata et al., 2007). In parallel, MR expression was detected in the distal colon of rat (Pressley and Funder, 1975), human (Lombes et al., 1984) and chick (Rafestin-Oblin et al., 1989), and in airway epithelia from bronchiole to trachea (Krozowski and Funder, 1981), in the salivary (Funder et al., 1972) and sweat glands (Kenouch et al., 1994), in the liver (Duval and Funder, 1974) and in the inner ear (Furuta et al., 1994; Nevoux et al., 2015; Pitovski et al., 1993; Teixeira et al., 2006). Subsequently, MR expression was intriguingly detected in non-epithelial tissues. Indeed, specific aldosterone-binding sites were revealed in mononuclear leukocytes (Armanini et al., 1985) and macrophages (Lim et al., 2007). Thereafter, MR expression was detected in the hippocampus, which is a brain structure involved in many cognitive processes (Herman et al., 1989; Van Eekelen et al., 1988) suggesting that aldosterone and MR may be involved in memory processes (Pavlides and McEwen, 1999). In 1992, the discovery of MR expression in the heart and in the large vessels further broadened the field of investigation into the mechanism of action of aldosterone and its receptor and allowed research to be directed towards previously unsuspected pharmacological and therapeutic perspectives, particularly in the field of cardiology. Immunohistochemistry showed that MR was clearly expressed in myocytes and in endothelial cells of the atria and ventricles in rabbits. In large vessels, MR was found in the aorta and pulmonary artery, particularly in endothelial cells and vascular smooth muscle cells (Lombès M et al., 1992). Interestingly, MR expression was also demonstrated in 
skin, a stratified epithelium in which no ion transport had been clearly established even though amphibian skin had long been known as the site of ion transport (Kenouch et al., 1994; Sainte Marie et al., 2007). More intriguingly, MR expression was detected in adipose tissues, in which MR was shown to play a pivotal role in white adipocyte differentiation (Caprio et al., 2007; Rondinone et al., 1993). In addition, our group identified the brown adipose tissue as a novel target for aldosterone action (Zennaro et al., 1998) and demonstrated that aldosterone is capable of inducing differentiation of brown adipocytes (Penfornis et al., 2000) and exerts a control on energy balance. This list of MR expression in tissues is far from being exhaustive. Indeed, MR is also expressed in several structures of the eyeball such as the retina, the pigmentary epithelium, the ciliary bodies of the iris and the cornea (Mirshahi et al., 1997; Schwartz and Wysocki, 1997). MR is also expressed in placenta (Hirasawa et al., 2000), uterus, ovaries and testes, spleen and smooth muscle (Le Menuet et al., 2000a). Thus, this broad tissue expression of MR strongly suggests that MR exerts functions other than those previously described in polarized epithelial tissues. 


\subsubsection{Mechanism of MR Action in a Renal Polarized Epithelial Cell}

In a typical polarized epithelial principal cell of the distal nephron, aldosterone enters cells by passive diffusion and binds to the MR (Figure 2). This latter is exclusively located in the cytoplasm in the absence of its ligand and is complexed with various chaperon proteins (hsp70, hsp90, Cyp40, FKBP52). Then, the binding of aldosterone to MR induces dissociation of these chaperon proteins and conformational changes of the receptor. After translocation to the nuclear compartment, the hormone-receptor complex binds mostly as homodimers to specific DNA sequences, identified as Mineralocorticoid Response Elements (MREs), which are in the regulatory regions of aldosterone-sensitive genes. The consensus sequence of these MREs corresponds to a 15-nucleotide-sequence AGaACAgxaTGTtCt consisting of partial palindromic motif as identified by Chromatin Immunoprecipitation assays followed by DNA sequencing (ChIP-Seq) (Le Billan et al., 2015). Thereafter, MR interacts, in a cyclic, sequential and/or combinatorial manner (Le Billan et al., 2018), with several transcriptional coregulators and some basal transcription factors or components of the machinery to enhance transcriptional activation (initiation and elongation) and to facilitate chromatin remodeling involving histone acetylation/methylation (Le Billan et al., 2015). In epithelial tissues (kidney and colon), MR stimulates expression of ionic transporters: the Epithelial $\mathrm{Na}^{+}$Channel $(\mathrm{ENaC})$ and the basolateral $\mathrm{Na}^{+}, \mathrm{K}^{+}$-ATPase pump, which are involved in the unidirectional transepithelial sodium transport from the lumen to the interstitium. The Serum and glucocorticoid-regulated kinase 1 ( $\operatorname{sgk} 1)$ is the most studied aldosterone-stimulated gene in epithelial tissues, which phosphorylates the ubiquitin ligase Nedd4-2, which in turn controls the retrieval of the subunits of $\mathrm{ENaC}$ from the apical membrane of the cell. Several other target genes have been identified such as the Glucocorticoid-Induced Leucine Zipper protein (GILZ), the serine/threonine kinase KS-WNK1 (With No lysine K kinase), the N-myc Down-Regulated Gene 2 (NDRG2), or the small monomeric GTP-binding protein Kirsten Ras (Ki-Ras), which also seem to play pivotal 
roles during the early phase of aldosterone responses in the nephron (Viengchareun et al., 2007; Laulhé et al., 2021). The PERl gene has recently been identified as another aldosterone-target gene in the kidney (Gumz et al., 2009), suggesting that aldosterone may also regulate the rhythmicity of renal sodium reabsorption since PER1 belongs to the circadian clock gene family. Beyond this classical model of aldosterone action, recent data obtained from $\mathrm{ChIP}$ experiments revealed that $\mathrm{MR}$ can also indirectly bind to recognition motifs for other transcription factors (FOX, EGR1, AP1, PAX5), suggesting functional interactions of MR with other transcription factors through tethering mechanisms, thus enabling the modulation of target gene expression (Le Billan et al., 2015).

\subsubsection{Regulation of MR expression}

The $N R 3 C 2$ gene expression is controlled by two alternative promoters (Zennaro et al., 1996). The proximal P1 promoter, corresponding to the $5^{\prime}$-flanking region of exon $1 \alpha$ of $N R 3 C 2$ gene, is a relatively strong promoter that is transcriptionally active in all aldosterone target tissues, whereas the distal P2 promoter, flanking exon $1 \beta$ of $N R 3 C 2$ gene, is weaker and has a more restricted pattern of expression, notably in the central nervous system (Le Menuet et al., 2000b). Alternative transcription of these two 5'-untranslated exons ( $1 \alpha$ and $1 \beta)$ generates two mRNA isoforms, referred to as $\mathrm{hMR} \alpha$ and $\mathrm{hMR} \beta$, which give rise to the same MR protein (Zennaro et al., 1995). Interestingly, several other MR splice variants, lacking one ( $\Delta 6 \mathrm{MR})$ or two exons $(\Delta 5,6 \mathrm{MR})$, have been identified so far and such splice variants seem to play major roles in modulating receptor function (Lema et al., 2017a; Zennaro et al., 2001). 
MR transcripts stability is also regulated at the posttranscriptional level. This is particularly relevant in the nephron where MR expression was recently shown to be modulated by large variations of extracellular tonicity, prevailing in the renal tubules (Viengchareun et al., 2009). Indeed, hypertonicity was shown to greatly decrease MR transcript levels by recruiting the RNA Binding Protein (RBP) Tis11b (tetradecanoyl phorbol acetate inducible sequence 11b), which physically interacts with MR transcript 3'-untranslated region (3'-UTR), thus modulating its mRNA turnover in response to osmotic stress (Viengchareun et al., 2014). Conversely, MR transcript and protein levels were shown to increase under hypotonicity by recruiting HuR (Human antigen R), another RBP member of the Hu family. Under hypotonic stress, and rapidly exported from the nuclear compartment to the cytoplasm of renal cells where it interacts with MR 3'-UTR to stabilize and increase MR levels, thereby modulating MR signaling (Lema et al., 2017b). During this past decade, microRNAs (miRNAs) have also emerged as a new class of posttranscriptional regulators (Bartel, 2004; Ozbaki-Yagan et al., 2020). Taken together, RNA Binding Protein and miRNAs seem to be of particular importance in the control of MR expression, presumably during the prenatal period and notably at birth, where renal MR expression is downregulated, accounting for the transient physiological renal resistance to aldosterone observed in the early neonatal period (Martinerie et al., 2009b).

\subsubsection{Mineralocorticoid Selectivity Mechanism}

In the absence of a mineralocorticoid selectivity mechanism, MR would be permanently occupied by glucocorticoid hormones since plasma concentration of these hormones is 100 to 1000 times higher than that of aldosterone in mammals, depending on the nychthemeral cycle of glucocorticoid hormones. This illicit occupation of the MR by glucocorticoid hormones is explained by the homology existing between the biochemical structure of aldosterone and cortisol and the high homology between the MR and the GR (Glucocorticoid Receptor). Indeed, 
the DBD and LBD of MR have, respectively, 94\% and 57\% identity with those of GR (Arriza et al., 1987). Moreover, these two receptors bind to the same GRE sequences and in vitro experiments have shown that affinity of MR is identical for aldosterone and glucocorticoid hormones (Arriza et al., 1987; Funder et al., 1988). The main mechanism responsible for mineralocorticoid selectivity relies on the $11 \beta$-hydroxysteroid dehydrogenase type II (11ßHSD2), an enzyme belonging to the superfamily of short-chain alcohol dehydrogenases (Edwards et al., 1988; Funder et al., 1988; Jörnvall et al., 1995). This enzyme has a high affinity for glucocorticoid hormones and oxidizes the alcohol function carried by carbon 11 of the glucocorticoid hormones into a ketone function, thus producing $11 \beta$-dehydrogenated derivatives (cortisone for cortisol in humans and 11-dehydrocorticosterone for corticosterone in rodents) that have little or no affinity for MR, or even for GR (Funder et al., 1988). In cells co-expressing MR and 11ßHSD2, the illicit occupation of the MR by glucocorticoid hormones is thus clearly limited by the action of this enzyme, allowing aldosterone to act selectively onto its receptor in order to specifically exert its biological effects on sodium reabsorption. Of note, mineralocorticoid selectivity is also ensured by an intrinsic property of the receptor since MR can discriminate between aldosterone and glucocorticoids because dissociation rates (k-1) are much faster for glucocorticoids than for aldosterone. Moreover, it has been shown that the aldosterone-MR complex adopts structural conformation somehow different from that of the glucocorticoid-MR complex, thereby allowing distinct interaction between the N-terminal domain and the LBD to occur. Thus, specific coactivators may be recruited resulting in a highly specific transcriptional response (Farman and Rafestin-Oblin, 2001). Recently, it has also been demonstrated that specific cyclical and dynamic interaction of MR with DNA, as a function of the nature of the MR-bound ligand, is responsible for distinct transcriptional signatures (Le Billan et al., 2018). 


\section{Ontogenesis of the Adrenal Gland and Mineralocorticoid Signaling Pathway Throughout Evolution}

\subsection{Ontogenesis of corticosteroid receptors during evolution}

The corticosteroid signaling system in fish clearly differs from that of mammals (Kiilerich et al., 2015). In fish, cortisol is the major corticosteroid while aldosterone seems to be lacking (Jiang et al., 1998; Prunet et al., 2006). Consequently, cortisol not only regulates energy metabolism but also hydromineral homeostasis notably during seawater and freshwater adaptation and via chloride cell function. Whether cortisol acts through the GR or MR remained a subject of debate for a long period of time. In the zebrafish, some authors demonstrated that cortisol could also activate the GR and functions as a mineralocorticoid by affecting epidermal ionocyte development and ion transport (Cruz et al., 2013; Kumai et al., 2012). Moreover, deoxycorticosterone (DOC), seems to be able to specifically bind and activate MR (Sturm et al., 2005).

Two GR isoforms (GR1 and GR2), probably raising from the 350 Million years ago whole genome duplication, have been described in many fishes while the MR seems to derive from the ancestral Corticosteroid Receptor (CR), expressed in the lamprey and hagfish (Baker, 2019), however its role remains to be further clarified. Ontogenesis of MR and GR during evolution revealed that both receptor expressions appeared in the Chondrichthyes, including sharks and that they are also expressed in the teleost fish such as Holostei and Sturgeons. Aldosterone was first detected in the lungfish and remains detected in the subsequent vertebrates: frogs, salamanders, turtles, lizards, snakes, crocodiles, birds, and mammals (Figure 3).

Recently, progesterone was shown to be an MR agonist in a range of teleost fish (Pippal et al., 2011; Baker and Katsu, 2017; Katsu et al., 2018; Fuller et al., 2021). This rather unexpected 
result could be explained by the demonstration that leucine substitution by serine or threonine at position 810 in helix-5 of the MR LBD enables contact with an alanine at position 773 in helix-3, suggesting that helix-3/helix-5 interaction is critical for ligand-dependent MR activation (Geller et al., 2000; Zhang et al., 2005; Fuller et al., 2019).

\subsection{Ontogenesis of adrenal glands in Amphibians}

Like in mammals, the adrenal gland in amphibian is constituted of two tissues, different in function and in embryonic origin: the chromaffin tissue that produces the catecholamines and the steroidogenic tissue that produces glucocorticoid, mineralocorticoid, and androgenic hormones (Norris and Carr, 2013). In amphibians, the primary glucocorticoid is corticosterone. While the adrenals in mammals have a characteristic cortical-medullary organization with distinct zonation, such distinctions are lacking in non-mammalian species. In Anurans, adrenocortical tissue corresponds to irregular nodules organized into a pair of inter-renal glands on the ventral surface of the kidneys. The glandular pattern is, on one hand, more medial and diffuse in frogs of the more primitive families and, on the other hand, more lateral and aggregated in the more advanced families (Milano and Accordi, 1986). In Urodeles, the adrenal glandular structure is variable without a clear taxonomic pattern, although increased compactness of the gland and mingling of steroidogenic and chromaffin cells can be found. The compactness and aggregation of chromaffin and steroidogenic tissues therefore increase in the transition from primitive to advanced families, both in urodeles and anurans. Ontogenesis of the gland is similar in all amphibians studied. The chromaffin originates from neural crest cells by migration and the primordium of the steroidogenic tissue coincides with or is near to the mesonephric blastema. In Anuran, the gland develops on the kidney of mesonephric type by a moderate cell proliferation of the dorsal root of the dorsal mesentery leading to the interrenal tissue, homologous with the mammal's adrenal cortex. The persistence of the mesonephros will 
preserve the contact established between the two organs during ontogenesis. Until the end of metamorphosis (biological process by which larva physically transforms after birth into an adult, involving a conspicuous and relatively abrupt change in the animal's body structure, allowing evolution from aquatic to a terrestrial or semi-terrestrial lifestyle), morphogenesis of the adrenal gland is similar in all amphibians studied. After metamorphosis in the advanced anurans, the adrenal gland may reach its definitive position before sexual maturity by various means, among which active cellular movements prevail. The inter-renal gland is generally more active just before metamorphosis and metamorphic climax. The corticosteroids (CS) plasma levels are low-to-nondetectable before metamorphosis, but increase significantly at metamorphic climax, in parallel with the rise in thyroid hormones (TH), the metamorphosis trigger (Jaudet and Hatey, 1984). Surprisingly, whole-body CS content increases before metamorphosis and then declines to be low at metamorphic climax or in some cases shows a small increase at metamorphic climax (Glennemeier and Denver, 2002; Kloas et al., 1997). Whether these findings represent species differences or whether changes in wholebody CS content are not representative of changes in plasma concentrations is currently unknown. Aldosterone plasma levels first show a significant peak at the beginning of the climax and again at the middle of the climax. Whole-body aldosterone peak production is detected before metamorphosis and declines thereafter as observed for corticosteroids (Glennemeier and Denver, 2002; Kloas et al., 1997).

The neuroendocrine system regulates the production of hormones by the adrenal and thyroid glands (Denver, 2009a). Hypothalamic corticotropin-releasing factor (CRF) is a common, central regulator of pituitary adrenocorticotropic hormone (ACTH) secretion and thyroidstimulating hormone (TSH) in tadpoles. By regulating TSH and ACTH secretion, and consequently the production of $\mathrm{TH}$ and $\mathrm{CS}$, CRF controls the timing of metamorphosis integrating developmental progression and environmental signals. Thus, TH is considered as 
the primary morphogen of metamorphosis, while CS synergize with $\mathrm{TH}$ to promote metamorphic changes (Denver, 2009b). Aldosterone could play a part in the differentiation of adult skin and a role in the conquest of land (Colombo et al., 2006). However, the history of CS seems more linked to the struggle for survival and environmental resources (Denver, 2009b). Interestingly, mast cells, implicated in the regulation of aldosterone secretion, primarily appear in amphibian and their density follows a seasonal variation, with a rise in summer, linked to metamorphosis and amphibians' way out of water (Lopez et al., 2020).

\subsection{Ontogenesis of the adrenal gland and the mineralocorticoid pathway in}

\section{Mammals}

\subsubsection{Zona Glomerulosa and CYP11B2 Expression}

The adrenal cortex originates from the intermediate mesoderm while the medulla develops from the neuroectoderm and colonizes the adrenal cortex around 6-7 GW. In humans, the coelomic epithelium proliferates starting from $4 \mathrm{GW}$ to form the urogenital crest, which will give rise to the adrenal glands as well as the gonads and the kidneys. Then, the adrenogonadal primordium individualizes from the renal outline, and splits into the gonadal and adrenal primordium. Around $8 \mathrm{GW}$ in humans, two different histological layers appear within the adrenal primordium, composed of the external definitive zone (DZ), and the internal fetal zone (FZ), which represents $80 \%$ of the volume of the adrenal cortex at this stage. During the second trimester of gestation, a transition zone (TZ) individualizes between the definitive and fetal zones (Mesiano and Jaffe, 1997a). The fetal adrenal gland is dynamic with simultaneous proliferation of progenitor cells within the subcapsular layer, centripetal migration and cell apoptosis (Drelon et al., 2015), the latter being mainly localized in the internal compartment (Ishimoto and Jaffe, 2011). Many factors are involved in the human adrenal gland development i.e. hormonal factors, transcription factors and growth factors. ACTH is one of the main 
hormonal factor involved in this process, secreted as early as $8 \mathrm{GW}$ by the fetal pituitary (Ishimoto et al., 2006); however, it has been demonstrated that pituitary Luteinizing Hormone (LH) and placental human Chorionic Gonadotropin (hCG) also contribute to adrenal development (Kero et al., 2000). SF1 (Steroidogenic Factor 1) and DAX1 (DSS-AHC critical region on the $\mathrm{X}$ chromosome, gene 1) are two essential transcription factors involved in adrenal cortex development, both being expressed from 33 days post-conception within the adrenogonadic primordium (Suntharalingham et al., 2015). SF1 acts as a regulator of many genes involved in steroidogenesis including the ACTH receptor gene, StAR, CYP17, HSD3B1, CYP21, and CYP11B1. In addition, DAX1 and SF1 demonstrate complex functional interactions. Indeed, DAX1 is a transcription repressor of SF1 target genes, such as StAR, and is able to inhibit transcriptional activation mediated by SF1 (Lalli and Alonso, 2010). The adrenal gland development is also regulated by many growth factors such as bFGF (basic Fibroblast Growth Factor), EGF (Epidermal Growth Factor), IGF-I (Insulin-like Growth Factor I), IGF-II (Insulin-like Growth Factor II), and the TGF $\beta$ (Transforming Growth Factor $\beta$ ) family. For example, IGF-II is thought to stimulate the proliferation of steroidogenic cells and is involved in the activation of steroidogenesis mediated by ACTH (Mesiano and Jaffe, 1997b). The three areas of the fetal cortex (ZD, ZT and ZF) are morphologically and functionally different, depending on the selective expression of genes involved in steroidogenesis, thus allowing specificity for hormone biosynthesis (Narasaka et al., 2001). The definitive zone expresses both the 3ßHSD2 and CYP11B2 enzymes allowing for aldosterone biosynthesis. Recent studies showed that $3 \beta \mathrm{HSD} 2$ is expressed starting from $18 \mathrm{GW}$ in both definitive and fetal zones whereas expression of CYP11B2 only appears around $24 \mathrm{GW}$ and is restricted to the subcapsular layer of the adrenal gland (Coulter and Jaffe, 1998; Naccache et al., 2016). This relatively late expression may explain the absence of detection of plasma aldosterone in fetuses from 9 to $20 \mathrm{GW}$ (Johnston et al., 2018). Recent studies have also 
demonstrated a delayed CYP11B1 activity both in the ZD and ZT (Kamrath et al., 2014; Travers et al., 2018). Aldosterone production begins during fetal life with detectable plasma concentrations in premature newborns as early as 25 GW (Bourchier, 2005; Martinerie et al., 2015). Plasma aldosterone concentration increases until term (Martinerie et al., 2015), in relation to a fetal neo-synthesis (Bayard et al., 1970).

In mice, organogenesis of the adrenal gland follows the same developmental stages during gestation (which lasts approximately 21 days long). It begins on the $9^{\text {th }}$ day of gestation (E9). Zoning begins around E12, and the different areas of the cortex are identifiable at E16. Plasma aldosterone concentrations are detected in the fetus as early as E16 (Wotus et al., 1998). Thus, the establishment of aldosterone biosynthesis from the fetal stage appears as wellpreserved among mammals. At birth, the adrenal gland in a full-term newborn is capable of secreting large amounts of aldosterone, with circulating concentrations usually 10 -fold higher than in an adult. Plasma aldosterone concentration will then decrease gradually during the first year of life in humans to reach concentrations close to that of the adult, around the age of 1 year (Martinerie et al., 2015).

\subsubsection{MR, $11 \beta H S D 2$ and Target Genes}

MR expression during renal development shows a particular profile with a biphasic expression. It is followed in parallel by all the other players of the mineralocorticoid signaling pathway, expressed in the distal parts of the nephron (11ßHSD2 enzyme and target genes). This biphasic renal expression profile is extremely well-preserved between mice and humans (Figure 4). Renal expression of MR, 11ßHSD2, and MR target genes is transient during gestation (between 15 and 30-34 GW in humans; and E16 and E18 in mice), then subsequently decreases as the term of birth approaches, before increasing again during the postnatal period, after the first week of life in mice. Renal expression of MR then increases very gradually during 
the first year of life in humans, along with the decrease in plasma aldosterone concentrations (Martinerie et al., 2009b). Thus, the mineralocorticoid signaling pathway is repressed in the kidney at birth, both in mice and humans. In contrast, this expression pattern is not identical in other organs where the mineralocorticoid signaling pathway is also expressed, such as the lung (Martinerie et al., 2013). Indeed, while in the heart and brain, expression of the MR and of the mineralocorticoid signaling pathway undergoes the same variation during development, the decrease of MR expression is not observed in the lung at the time of birth, where it is, on the contrary, maintained (Figure 4). The expression of this signaling pathway is therefore tissuespecific and variable during development, particularly in the renal tubule, identically between mice and humans, suggesting an important physiological role in the preparation and/or the adaptation to extrauterine life.

\section{Physiological Role During the Perinatal Period?}

It seems relevant to question the role of this tissue-specific and temporal expression pattern of the mineralocorticoid pathway during development. The first element to consider concerns the fetal period. Interestingly, both in mice and in humans, the appearance of MR at E16 and around 15-20 GW, respectively, corresponds to the initiation phase of skin keratinization (Underwood et al., 2005). It is, thus, highly possible that from this stage of development and onward the exchanges between fetal internal environment and the amniotic fluid are no longer passive, and that a mode of regulation at the renal level becomes necessary and pivotal. Subsequently, changes in renal MR expression could be related to variations of tonicity (and sodium content) of the surrounding environment (Underwood et al., 2005), somehow reminiscent of what is observed in fish. As mentioned in chapter 4.1, fishes, in particular salmons, express MR in their gills. When they acclimate from a freshwater environment to a saltwater environment during their life, MR expression adapts, being repressed, and inversely, 
upregulated when salmons return to freshwater, thus making it possible to maintain the water and sodium balance in the interior environment (Kiilerich et al., 2015). Similarly, the osmolality of the amniotic fluid is stable in mice up to E16.5, where it decreases sharply (in parallel with the increase in MR renal expression), preceding a sharp increase before birth (Cheung and Brace, 2005; Desai et al., 2003) which coincides with the decrease in renal MR expression (Martinerie et al., 2009b). In addition, in humans, after birth, the newborn kidney must adapt from an aquatic environment to an air environment. The newborn must adjust to a very low sodium intake from breast milk, which further decreases during the first days of life (Koo and Gupta, 1982) (again reflecting the gradual increase in renal MR expression after the first week of life). At birth, the newborn kidney lacks MR expression, thus making it unresponsive to aldosterone. As we have seen above, aldosterone is secreted in large quantities by the adrenal gland in late pregnancy and at birth. This relative renal resistance to its action leads to a state of transient pseudo-hypoaldosteronism, associating hyponatremia (by sodium depletion), hyperkalemia, urinary sodium and water losses, accounting for neonatal weight loss observed physiologically during the first days of life (Martinerie et al., 2009a). Conversely, expression of MR is maintained in the lung at birth. The lung can therefore respond to high concentrations of aldosterone, and thus allow the resorption of pulmonary fluid, through expression of ENaC, the alpha subunit being a target gene of the aldosterone-MR complex (Helve et al., 2004). Kidneys are then able to eliminate this excessive fluid. Finally, aldosterone could also have a direct role on the blood vessels and allow an increase in systemic vascular resistance at birth (Romagni et al., 2003). Aldosterone therefore appears to be a central hormone in the adaptation to extrauterine life. Interestingly, regarding evolution, aldosterone is first detected in the lungfish, primary living being able to breathe, and in amphibians, whose ancestors came out of water during the terrestrialization, emphasizing this hypothesis (Figure 3). 


\section{Animal Models and Pathophysiological Situations Demonstrating this}

\section{Central Role in Neonatal Adaptation}

\subsection{Defects in the Activation of the Mineralocorticoid Signaling Pathway}

The physiological importance of the mineralocorticoid signaling pathway is largely underscored by human pathologies as well as comforted by the phenotypes of recently generated knock-out animal models (both in mammals and in fish). The total as well as cellspecific gene inactivation have further deciphered the functional aspect and the molecular events involved in the mineralocorticoid signaling. Approximately one hundred MR loss-of function mutations presenting with a pseudohypoaldosteronism have been reported in humans (Zennaro and Fernandes-Rosa, 2017) as opposed to the unique MR gain-of-function mutation described in a family in which affected carriers presented with early arterial hypertension exacerbated during pregnancy (Geller et al., 1998). The major role of MR in sodium and water homeostasis has been further corroborated by the phenotype of animal models. For instance, total MR knock-out mouse model has been generated almost three decades ago (Berger et al., 1998) and demonstrated that despite a normal in utero development, newborn mice prematurely die at 10 days of life from severe salt and water wasting that could be partially successfully treated with salt supplementation through intra-peritoneal injections (Bleich et al., 1999). In addition, a siRNA strategy against MR in the rat (Lim et al., 2008) further demonstrated the importance of renal MR expression for an appropriate water and sodium homeostasis. Cellspecific and sometimes inducible MR gene invalidation including principal renal cells (Ronzaud et al., 2011), cardiomyocytes (Ouvrard-Pascaud et al., 2005), endothelial cell (Laursen et al., 2018), macrophage (Rickard et al., 2009), adipocyte (Caprio et al., 2007), neuronal (van Weert et al., 2019) have also elucidated key molecular events regulated by MR. Constitutive corticosteroid knockout zebrafish and medaka which constitute viable animal 
models of corticosteroid receptor gene inactivation have been generated (Sakamoto et al., 2018) and besides the role of MR in osmoregulation notably in mammals, these models allowed to point out towards a well conserved function of corticosteroid receptor in vertebrates integrating brain-behavior and visual responses, consistent with the presence of MR in the mammal retina (Zhao et al., 2012). These studies in fish underscore that MR signaling is clearly not restricted to osmoregulation but may have a wider physiological impact that remains to be further elucidated (Rossier, 2016). Concerning ligand inactivation in humans, approximately forty-five inactivating mutations of the CYP11B2 gene, encoding the cytochrome P450 enzyme aldosterone synthase responsible for aldosterone synthesis and production have been described to date (Miao et al., 2019). Aldosterone deficiency syndrome is a rare autosomal recessive disorder in infants characterized by hyponatremia, severe hyperkalemia, associated with salt wasting, dehydration and failure to thrive contrasting with low plasma aldosterone concentrations while 18-hydroxycorticosterone concentration might differentiate the level of enzymatic defect. The recent liquid chromatography coupled to mass spectrometry (LCMS/MS) method should now facilitate quantification and identification of appropriate steroid levels both in human plasma and urinary samples (Pussard et al., 2020; Travers et al., 2017). Genetic analyses, notably by next generation sequencing, demonstrated classical genetic alterations, the most common being missense and nonsense mutations, leading to an impaired enzymatic activity (Miao et al., 2019).

\subsection{Transient Pseudohypoaldosteronism}

In addition to these genetic diseases, there are pathological situations where a transient, nonphysiological pseudohypoaldosteronism appears (Bogdanović et al., 2009). These pseudohypoaldosteronisms result in hyponatremia, hyperkalemia, metabolic acidosis and severe dehydration with major urinary sodium loss. They are essentially linked to the occurrence of an infection of the upper urinary tract (pyelonephritis) with or without underlying 
uropathy; and have the particularity of occurring mainly in infants under 3 months of age, most notably in males (Bogdanović et al., 2009). They will disappear with the correction of the urinary tract infection, but during the acute phase, they will require active management by sodium and water supplementation. The pathophysiology may be related to low renal expression of the mineralocorticoid pathway during this period of life, and to inflammation (through the activation of NF-KB factor) that may further downregulate MR expression and activation (de Seigneux et al., 2008). The fact that boys seem more particularly affected, could be explained by a sexual dimorphism in the renal expression of the mineralocorticoid signaling pathway (Dumeige et al., 2017), making boys more sensitive to a decline in its expression.

\subsection{Specificity of the Premature Infants}

The mineralocorticoid signaling pathway seems essential in the postnatal period. Thus, it can be wondered if the premature infant, whose organ maturation is not yet completed, has the capacity to adapt at birth. Aldosterone secretion increases gradually during fetal life, starting from 25 GW (Bourchier, 2005; Martinerie et al., 2015). Very premature infants (birth before $32 \mathrm{GW}$ ), therefore have a limited capacity for aldosterone neo-synthesis (linked to an overall immaturity of the adrenal gland associated with a specific lack of biological activity of the 11$\beta$-hydroxylase enzyme (Kamrath et al., 2014; Travers et al., 2018). The adrenal gland is not able to adapt to neonatal changes, and aldosterone concentrations remain 3 to 4 times lower than in a full-term newborn (around $300 \mathrm{pg} / \mathrm{mL}$ compared to $1000 \mathrm{pg} / \mathrm{mL}$ on average, by RIA measurement) (Martinerie et al., 2015). It should be noted, however, that these concentrations are 4 times higher than that of an adult (on average $80 \mathrm{pg} / \mathrm{mL}$ ) again underlining the importance of this hormone, which must be secreted in large quantities, for optimal postnatal adaptation. Thus, despite a transient MR expression at the renal level in very premature infants between approximately 25 and $30 \mathrm{GW}$, allowing the kidney to respond transiently to the action of aldosterone (Martinerie et al., 2015, 2009b), the relatively low secretion of aldosterone does 
not permit an active sodium reabsorption during the first weeks of life. Likewise, the lung has difficulty reabsorbing alveolar fluid (Helve et al., 2004).

\section{Conclusions}

The mineralocorticoid signaling pathway therefore appears to be a primary pathway for adaptation to extrauterine life. Regarding evolution, while MR is already expressed in fish, involved in the regulation of sodium homeostasis between freshwater and saltwater, fine regulation of the mineralocorticoid pathway appears with its main hormone, aldosterone, in one of the first living being that evolves outside water, the amphibian. Similarly, aldosterone secretion increases throughout gestation in mammals, preparing the fetus for its extrauterine life, reaching levels in full-term newborns approximately 10-fold higher than that of the adults. Defects in aldosterone production or activation of the mineralocorticoid pathway result in neonatal maladaptation at birth. In premature newborns, due to the relative low levels of circulating aldosterone, a sodium wasting syndrome sets in, causing dehydration, hyponatremia and hyperkalemia, which can be life-threatening. Altogether, results obtained from comparative evolution and over the last ten years specifically in mammals, have shed light on a central role for mineralocorticoid signaling and have pointed out to new therapeutic opportunities for preventing urinary sodium loss in very premature infants. 


\section{References}

Armanini, D., Strasser, T., Weber, P.C., 1985. Characterization of aldosterone binding sites in circulating human mononuclear leukocytes. Am J Physiol 248, E388-390. https://doi.org/10.1152/ajpendo.1985.248.3.E388

Arriza, J.L., Weinberger, C., Cerelli, G., Glaser, T.M., Handelin, B.L., Housman, D.E., Evans, R.M., 1987. Cloning of human mineralocorticoid receptor complementary DNA: structural and functional kinship with the glucocorticoid receptor. Science 237, 268-275.

Baker, M.E., 2019. Steroid receptors and vertebrate evolution. Mol Cell Endocrinol 496, 110526. https://doi.org/10.1016/j.mce.2019.110526

Baker, M.E., Katsu, Y., 2017. 30 YEARS OF THE MINERALOCORTICOID RECEPTOR: Evolution of the mineralocorticoid receptor: sequence, structure and function. J Endocrinol 234, T1-T16. https://doi.org/10.1530/JOE-16-0661

Bartel, D.P., 2004. MicroRNAs: genomics, biogenesis, mechanism, and function. Cell 116, 281-297.

Bassett, M.H., White, P.C., Rainey, W.E., 2004. The regulation of aldosterone synthase expression. Mol Cell Endocrinol 217, 67-74. https://doi.org/10.1016/j.mce.2003.10.011

Bayard, F., Ances, I.G., Tapper, A.J., Weldon, V.V., Kowarski, A., Migeon, C.J., 1970. Transplacental passage and fetal secretion of aldosterone. J. Clin. Invest. 49, 1389-1393. https://doi.org/10.1172/JCI106356

Berger, S., Bleich, M., Schmid, W., Cole, T.J., Peters, J., Watanabe, H., Kriz, W., Warth, R., Greger, R., Schütz, G., 1998. Mineralocorticoid receptor knockout mice: pathophysiology of Na+ metabolism. Proc Natl Acad Sci U S A 95, 9424-9429. https://doi.org/10.1073/pnas.95.16.9424

Betancourt-Calle, S., Calle, R.A., Isales, C.M., White, S., Rasmussen, H., Bollag, W.B., 2001. Differential effects of agonists of aldosterone secretion on steroidogenic acute regulatory phosphorylation. Mol Cell Endocrinol 173, 87-94. https://doi.org/10.1016/s03037207(00)00411-1

Beuschlein, F., Boulkroun, S., Osswald, A., Wieland, T., Nielsen, H.N., Lichtenauer, U.D., Penton, D., Schack, V.R., Amar, L., Fischer, E., Walther, A., Tauber, P., Schwarzmayr, T., Diener, S., Graf, E., Allolio, B., Samson-Couterie, B., Benecke, A., Quinkler, M., Fallo, F., Plouin, P.-F., Mantero, F., Meitinger, T., Mulatero, P., Jeunemaitre, X., Warth, R., Vilsen, B., Zennaro, M.C., Strom, T.M., Reincke, M., 2013. Somatic mutations in ATP1A1 and ATP2B3 lead to aldosterone-producing adenomas and secondary hypertension. Nat Genet 45, 440-444, 444e12. https://doi.org/10.1038/ng.2550

Bleich, M., Warth, R., Schmidt-Hieber, M., Schulz-Baldes, A., Hasselblatt, P., Fisch, D., Berger, S., Kunzelmann, K., Kriz, W., Schütz, G., Greger, R., 1999. Rescue of the mineralocorticoid receptor knock-out mouse. Pflugers Arch 438, 245-254. https://doi.org/10.1007/s004240050906

Bockenhauer, D., Zieg, J., 2014. Electrolyte disorders. Clin Perinatol 41, 575-590. https://doi.org/10.1016/j.clp.2014.05.007

Bogdanović, R., Stajić, N., Putnik, J., Paripović, A., 2009. Transient type 1 pseudo-hypoaldosteronism: report on an eight-patient series and literature review. Pediatr Nephrol 24, 2167-2175. https://doi.org/10.1007/s00467-009-1285-8

Bonvalet, J.P., 1998. Regulation of sodium transport by steroid hormones. Kidney Int. Suppl. 65, S4956.

Bourchier, D., 2005. Plasma aldosterone levels in the 1st week of life in infants of less than 30 weeks gestation. Eur. J. Pediatr. 164, 141-145. https://doi.org/10.1007/s00431-004-1572-0

Caprio, M., Fève, B., Claës, A., Viengchareun, S., Lombès, M., Zennaro, M.-C., 2007. Pivotal role of the mineralocorticoid receptor in corticosteroid-induced adipogenesis. FASEB J. 21, 21852194. https://doi.org/10.1096/fj.06-7970com

Cheung, C.Y., Brace, R.A., 2005. Amniotic fluid volume and composition in mouse pregnancy. J. Soc. Gynecol. Investig. 12, 558-562. https://doi.org/10.1016/j.jsgi.2005.08.008 
Choi, M., Scholl, U.I., Yue, P., Björklund, P., Zhao, B., Nelson-Williams, C., Ji, W., Cho, Y., Patel, A., Men, C.J., Lolis, E., Wisgerhof, M.V., Geller, D.S., Mane, S., Hellman, P., Westin, G., Åkerström, G., Wang, W., Carling, T., Lifton, R.P., 2011. K+ channel mutations in adrenal aldosterone-producing adenomas and hereditary hypertension. Science 331, 768-772. https://doi.org/10.1126/science.1198785

Colombo, L., Valle, L.D., Fiore, C., Armanini, D., Belvedere, P., 2006. Aldosterone and the conquest of land. J Endocrinol Invest 29, 373-379. https://doi.org/10.1007/BF03344112

Coulter, C.L., Jaffe, R.B., 1998. Functional maturation of the primate fetal adrenal in vivo: 3. Specific zonal localization and developmental regulation of CYP21A2 (P450c21) and CYP11B1/CYP11B2 (P450c11/aldosterone synthase) lead to integrated concept of zonal and temporal steroid biosynthesis. Endocrinology 139, 5144-5150. https://doi.org/10.1210/endo.139.12.6333

Cruz, S.A., Lin, C.-H., Chao, P.-L., Hwang, P.-P., 2013. Glucocorticoid receptor, but not mineralocorticoid receptor, mediates cortisol regulation of epidermal ionocyte development and ion transport in zebrafish (danio rerio). PLoS One 8, e77997. https://doi.org/10.1371/journal.pone.0077997

de Seigneux, S., Leroy, V., Ghzili, H., Rousselot, M., Nielsen, S., Rossier, B.C., Martin, P.-Y., Féraille, E., 2008. NF-kappaB inhibits sodium transport via down-regulation of SGK1 in renal collecting duct principal cells. J Biol Chem 283, 25671-25681. https://doi.org/10.1074/jbc.M803812200

Denver, R.J., 2009a. Structural and Functional Evolution of Vertebrate Neuroendocrine Stress Systems. Annals of the New York Academy of Sciences 1163, 1-16. https://doi.org/10.1111/j.17496632.2009.04433.x

Denver, R.J., 2009b. Stress hormones mediate environment-genotype interactions during amphibian development. General and Comparative Endocrinology 164, 20-31. https://doi.org/10.1016/j.ygcen.2009.04.016

Desai, M., Ladella, S., Ross, M.G., 2003. Reversal of pregnancy-mediated plasma hypotonicity in the near-term rat. J. Matern. Fetal. Neonatal. Med. 13, 197-202. https://doi.org/10.1080/jmf.13.3.197.202

Devuyst, O., 2008. Salt wasting and blood pressure. Nat Genet 40, 495-496. https://doi.org/10.1038/ng0508-495

Drelon, C., Berthon, A., Mathieu, M., Martinez, A., Val, P., 2015. Adrenal cortex tissue homeostasis and zonation: A WNT perspective. Mol Cell Endocrinol 408, 156-164. https://doi.org/10.1016/j.mce.2014.12.014

Dumeige, L., Storey, C., Decourtye, L., Nehlich, M., Lhadj, C., Viengchareun, S., Kappeler, L., Lombès, M., Martinerie, L., 2017. Sex-Specificity of Mineralocorticoid Target Gene Expression during Renal Development, and Long-Term Consequences. Int J Mol Sci 18. https://doi.org/10.3390/ijms 18020457

Duval, D., Funder, J.W., 1974. The binding of tritiated aldosterone in the rat liver cytosol. Endocrinology 94, 575-579. https://doi.org/10.1210/endo-94-2-575

Edwards, C.R., Stewart, P.M., Burt, D., Brett, L., McIntyre, M.A., Sutanto, W.S., de Kloet, E.R., Monder, C., 1988. Localisation of 11 beta-hydroxysteroid dehydrogenase--tissue specific protector of the mineralocorticoid receptor. Lancet 2, 986-989.

Fan, Y.S., Eddy, R.L., Byers, M.G., Haley, L.L., Henry, W.M., Nowak, N.J., Shows, T.B., 1989. The human mineralocorticoid receptor gene (MLR) is located on chromosome 4 at q31.2. Cytogenet. Cell Genet. 52, 83-84.

Farman, N., Rafestin-Oblin, M.E., 2001. Multiple aspects of mineralocorticoid selectivity. Am. J. Physiol. Renal Physiol. 280, F181-192.

Fernandes-Rosa, F.L., Daniil, G., Orozco, I.J., Göppner, C., El Zein, R., Jain, V., Boulkroun, S., Jeunemaitre, X., Amar, L., Lefebvre, H., Schwarzmayr, T., Strom, T.M., Jentsch, T.J., Zennaro, M.-C., 2018. A gain-of-function mutation in the CLCN2 chloride channel gene causes primary aldosteronism. Nat Genet 50, 355-361. https://doi.org/10.1038/s41588-018-0053-8

Fuller, P.J., Yao, Y.-Z., Jin, R., He, S., Martín-Fernández, B., Young, M.J., Smith, B.J., 2019. Molecular evolution of the switch for progesterone and spironolactone from mineralocorticoid receptor agonist to antagonist. Proc Natl Acad Sci U S A 116, 18578-18583. https://doi.org/10.1073/pnas.1903172116 
Fuller, P.J., Yao, Y.-Z., Yang, J., Young, M.J., 2021. Structural determinants of activation of the mineralocorticoid receptor: an evolutionary perspective. J Hum Hypertens 35, 110-116. https://doi.org/10.1038/s41371-020-0360-2

Funder, J.W., Feldman, D., Edelman, I.S., 1972. Specific aldosterone binding in rat kidney and parotid. J. Steroid Biochem. 3, 209-218.

Funder, J.W., Pearce, P.T., Smith, R., Smith, A.I., 1988. Mineralocorticoid action: target tissue specificity is enzyme, not receptor, mediated. Science 242, 583-585.

Furuta, H., Mori, N., Sato, C., Hoshikawa, H., Sakai, S., Iwakura, S., Doi, K., 1994. Mineralocorticoid type I receptor in the rat cochlea: mRNA identification by polymerase chain reaction (PCR) and in situ hybridization. Hear Res 78, 175-180. https://doi.org/10.1016/0378-5955(94)90023-x

Geller, D.S., Farhi, A., Pinkerton, N., Fradley, M., Moritz, M., Spitzer, A., Meinke, G., Tsai, F.T., Sigler, P.B., Lifton, R.P., 2000. Activating mineralocorticoid receptor mutation in hypertension exacerbated by pregnancy. Science 289, 119-123.

Geller, D.S., Rodriguez-Soriano, J., Vallo Boado, A., Schifter, S., Bayer, M., Chang, S.S., Lifton, R.P., 1998. Mutations in the mineralocorticoid receptor gene cause autosomal dominant pseudohypoaldosteronism type I. Nat Genet 19, 279-281. https://doi.org/10.1038/966

Glennemeier, K.A., Denver, R.J., 2002. Small changes in whole-body corticosterone content affect larval Rana pipiens fitness components. General and Comparative Endocrinology 127, 16-25. https://doi.org/10.1016/S0016-6480(02)00015-1

Gumz, M.L., Stow, L.R., Lynch, I.J., Greenlee, M.M., Rudin, A., Cain, B.D., Weaver, D.R., Wingo, C.S., 2009. The circadian clock protein Period 1 regulates expression of the renal epithelial sodium channel in mice. J Clin Invest 119, 2423-2434. https://doi.org/10.1172/JCI36908

Gunn, T.R., Mora, J.D., Pease, P., 1988. Outcome after antenatal diagnosis of upper urinary tract dilatation by ultrasonography. Archives of Disease in Childhood 63, 1240-1243. https://doi.org/10.1136/adc.63.10.1240

Hasler, U., Mordasini, D., Bianchi, M., Vandewalle, A., Féraille, E., Martin, P.-Y., 2003. Dual influence of aldosterone on AQP2 expression in cultured renal collecting duct principal cells. J Biol Chem 278, 21639-21648. https://doi.org/10.1074/jbc.M212388200

Hattangady, N.G., Olala, L.O., Bollag, W.B., Rainey, W.E., 2012. Acute and chronic regulation of aldosterone production. Mol Cell Endocrinol 350, 151-162. https://doi.org/10.1016/j.mce.2011.07.034

Helve, O., Pitkänen, O.M., Andersson, S., O’Brodovich, H., Kirjavainen, T., Otulakowski, G., 2004. Low expression of human epithelial sodium channel in airway epithelium of preterm infants with respiratory distress. Pediatrics 113, 1267-1272. https://doi.org/10.1542/peds.113.5.1267

Herman, J.P., Patel, P.D., Akil, H., Watson, S.J., 1989. Localization and regulation of glucocorticoid and mineralocorticoid receptor messenger RNAs in the hippocampal formation of the rat. Mol. Endocrinol. 3, 1886-1894. https://doi.org/10.1210/mend-3-11-1886

Hirasawa, G., Takeyama, J., Sasano, H., Fukushima, K., Suzuki, T., Muramatu, Y., Darnel, A.D., Kaneko, C., Hiwatashi, N., Toyota, T., Nagura, H., Krozowski, Z.S., 2000. 11Betahydroxysteroid dehydrogenase type II and mineralocorticoid receptor in human placenta. J. Clin. Endocrinol. Metab. 85, 1306-1309. https://doi.org/10.1210/jcem.85.3.6429

Ishimoto, H., Ginzinger, D.G., Jaffe, R.B., 2006. Adrenocorticotropin preferentially up-regulates angiopoietin 2 in the human fetal adrenal gland: implications for coordinated adrenal organ growth and angiogenesis. J Clin Endocrinol Metab 91, 1909-1915. https://doi.org/10.1210/jc.2005-2252

Ishimoto, H., Jaffe, R.B., 2011. Development and function of the human fetal adrenal cortex: a key component in the feto-placental unit. Endocr Rev 32, 317-355. https://doi.org/10.1210/er.20100001

Jaudet, G.J., Hatey, J.L., 1984. Variations in aldosterone and corticosterone plasma levels during metamorphosis in Xenopus laevis tadpoles. General and Comparative Endocrinology 56, 59 65. https://doi.org/10.1016/0016-6480(84)90061-3

Jiang, J.Q., Young, G., Kobayashi, T., Nagahama, Y., 1998. Eel (Anguilla japonica) testis 11 betahydroxylase gene is expressed in interrenal tissue and its product lacks aldosterone synthesizing activity. Mol Cell Endocrinol 146, 207-211. https://doi.org/10.1016/s0303-7207(98)00147-6 
Johnston, Z.C., Bellingham, M., Filis, P., Soffientini, U., Hough, D., Bhattacharya, S., Simard, M., Hammond, G.L., King, P., O’Shaughnessy, P.J., Fowler, P.A., 2018. The human fetal adrenal produces cortisol but no detectable aldosterone throughout the second trimester. BMC Med 16, 23. https://doi.org/10.1186/s12916-018-1009-7

Jörnvall, H., Persson, B., Krook, M., Atrian, S., Gonzàlez-Duarte, R., Jeffery, J., Ghosh, D., 1995. Shortchain dehydrogenases/reductases (SDR). Biochemistry 34, 6003-6013. https://doi.org/10.1021/bi00018a001

Kamrath, C., Hartmann, M.F., Boettcher, C., Wudy, S.A., 2014. Reduced activity of $11 \beta$-hydroxylase accounts for elevated 17 $\alpha$-hydroxyprogesterone in preterms. J Pediatr 165, 280-284. https://doi.org/10.1016/j.jpeds.2014.04.011

Katsu, Y., Oka, K., Baker, M.E., 2018. Evolution of human, chicken, alligator, frog, and zebrafish mineralocorticoid receptors: Allosteric influence on steroid specificity. Sci Signal 11, eaao1520. https://doi.org/10.1126/scisignal.aao1520

Kenouch, S., Lombes, M., Delahaye, F., Eugene, E., Bonvalet, J.P., Farman, N., 1994. Human skin as target for aldosterone: coexpression of mineralocorticoid receptors and 11 beta-hydroxysteroid dehydrogenase. J. Clin. Endocrinol. Metab. 79, 1334-1341. https://doi.org/10.1210/jcem.79.5.7962326

Kero, J., Poutanen, M., Zhang, F.P., Rahman, N., McNicol, A.M., Nilson, J.H., Keri, R.A., Huhtaniemi, I.T., 2000. Elevated luteinizing hormone induces expression of its receptor and promotes steroidogenesis in the adrenal cortex. J Clin Invest 105, 633-641. https://doi.org/10.1172/JCI7716

Kiilerich, P., Triqueneaux, G., Christensen, N.M., Trayer, V., Terrien, X., Lombès, M., Prunet, P., 2015. Interaction between the trout mineralocorticoid and glucocorticoid receptors in vitro. J Mol Endocrinol 55, 55-68. https://doi.org/10.1530/JME-15-0002

Kloas, W., Reinecke, M., Hanke, W., 1997. Stage-Dependent Changes in Adrenal Steroids and Catecholamines during Development inXenopus laevis. General and Comparative Endocrinology 108, 416-426. https://doi.org/10.1006/gcen.1997.6998

Koo, W.W., Gupta, J.M., 1982. Breast milk sodium. Arch. Dis. Child. 57, 500-502. https://doi.org/10.1136/adc.57.7.500

Krozowski, Z., Funder, J.W., 1981. Mineralocorticoid receptors in the rat lung. Endocrinology 109, 1811-1813. https://doi.org/10.1210/endo-109-6-1811

Krozowski, Z.S., Rundle, S.E., Wallace, C., Castell, M.J., Shen, J.H., Dowling, J., Funder, J.W., Smith, A.I., 1989. Immunolocalization of renal mineralocorticoid receptors with an antiserum against a peptide deduced from the complementary deoxyribonucleic acid sequence. Endocrinology 125, 192-198. https://doi.org/10.1210/endo-125-1-192

Kumai, Y., Nesan, D., Vijayan, M.M., Perry, S.F., 2012. Cortisol regulates Na+ uptake in zebrafish, Danio rerio, larvae via the glucocorticoid receptor. Mol Cell Endocrinol 364, 113-125. https://doi.org/10.1016/j.mce.2012.08.017

Lalli, E., Alonso, J., 2010. Targeting DAX-1 in embryonic stem cells and cancer. Expert Opin Ther Targets 14, 169-177. https://doi.org/10.1517/14728220903531454

Laulhé, M., Dumeige, L., Vu, T.A., Hani, I., Pussard, E., Lombès, M., Viengchareun, S., Martinerie, L., 2021. Sexual Dimorphism of Corticosteroid Signaling during Kidney Development. Int J Mol Sci 22. https://doi.org/10.3390/ijms22105275

Laursen, S.B., Finsen, S., Marcussen, N., Quaggin, S.E., Hansen, P.B.L., Dimke, H., 2018. Endothelial mineralocorticoid receptor ablation does not alter blood pressure, kidney function or renal vessel contractility. PLoS One 13, e0193032. https://doi.org/10.1371/journal.pone.0193032

Le Billan, F., Amazit, L., Bleakley, K., Xue, Q.-Y., Pussard, E., Lhadj, C., Kolkhof, P., Viengchareun, S., Fagart, J., Lombès, M., 2018. Corticosteroid receptors adopt distinct cyclical transcriptional signatures. FASEB J. fj201800391RR. https://doi.org/10.1096/fj.201800391RR

Le Billan, F., Khan, J.A., Lamribet, K., Viengchareun, S., Bouligand, J., Fagart, J., Lombès, M., 2015. Cistrome of the aldosterone-activated mineralocorticoid receptor in human renal cells. FASEB J. 29, 3977-3989. https://doi.org/10.1096/fj.15-274266

Le Menuet, D., Viengchareun, S., Penfornis, P., Walker, F., Zennaro, M.C., Lombès, M., 2000a. Targeted oncogenesis reveals a distinct tissue-specific utilization of alternative promoters of the human mineralocorticoid receptor gene in transgenic mice. J. Biol. Chem. 275, 7878-7886. 
Le Menuet, D., Zennaro, M.C., Viengchareun, S., Lombès, M., 2000b. Transgenic mouse models to study human mineralocorticoid receptor function in vivo. Kidney Int. 57, 1299-1306. https://doi.org/10.1046/j.1523-1755.2000.00966.x

Lefebvre, H., Duparc, C., Naccache, A., Lopez, A.-G., Castanet, M., Louiset, E., 2019. Paracrine Regulation of Aldosterone Secretion in Physiological and Pathophysiological Conditions. Vitam Horm 109, 303-339. https://doi.org/10.1016/bs.vh.2018.10.001

Lema, I., Amazit, L., Lamribet, K., Fagart, J., Blanchard, A., Lombès, M., Cherradi, N., Viengchareun, S., 2017a. HuR-Dependent Editing of a New Mineralocorticoid Receptor Splice Variant Reveals an Osmoregulatory Loop for Sodium Homeostasis. Sci Rep 7, 4835. https://doi.org/10.1038/s41598-017-04838-8

Lema, I., Amazit, L., Lamribet, K., Fagart, J., Blanchard, A., Lombès, M., Cherradi, N., Viengchareun, S., 2017b. RNA-binding protein HuR enhances mineralocorticoid signaling in renal KC3AC1 cells under hypotonicity. Cell. Mol. Life Sci. https://doi.org/10.1007/s00018-017-2594-x

Lim, H.-Y., Müller, N., Herold, M.J., van den Brandt, J., Reichardt, H.M., 2007. Glucocorticoids exert opposing effects on macrophage function dependent on their concentration. Immunology 122, 47-53. https://doi.org/10.1111/j.1365-2567.2007.02611.x

Lim, H.-Y., van den Brandt, J., Fassnacht, M., Allolio, B., Herold, M.J., Reichardt, H.M., 2008. Silencing of the mineralocorticoid receptor by ribonucleic acid interference in transgenic rats disrupts endocrine homeostasis. Mol Endocrinol 22, 1304-1311. https://doi.org/10.1210/me.2007-0417

Lindower, J.B., 2017. Water balance in the fetus and neonate. Seminars in Fetal and Neonatal Medicine 22, 71-75. https://doi.org/10.1016/j.siny.2017.01.002

Lombes, M., Claire, M., Pinto, M., Michaud, A., Rafestin-Oblin, M.E., 1984. Aldosterone binding in the human colon carcinoma cell line HT29: correlation with cell differentiation. J. Steroid Biochem. 20, 329-333.

Lombès, M., Farman, N., Oblin, M.E., Baulieu, E.E., Bonvalet, J.P., Erlanger, B.F., Gasc, J.M., 1990. Immunohistochemical localization of renal mineralocorticoid receptor by using an antiidiotypic antibody that is an internal image of aldosterone. Proc Natl Acad Sci U S A 87, 10861088. https://doi.org/10.1073/pnas.87.3.1086

Lombès M, Oblin M E, Gasc J M, Baulieu E E, Farman N, Bonvalet J P, 1992. Immunohistochemical and biochemical evidence for a cardiovascular mineralocorticoid receptor. Circulation Research 71, 503-510. https://doi.org/10.1161/01.RES.71.3.503

Lopez, A.-G., Duparc, C., Naccache, A., Castanet, M., Lefebvre, H., Louiset, E., 2020. Role of Mast Cells in the Control of Aldosterone Secretion. Horm Metab Res 52, 412-420. https://doi.org/10.1055/a-1119-1063

MacKenzie, S.M., van Kralingen, J.C., Davies, E., 2019. Regulation of Aldosterone Secretion. Vitam Horm 109, 241-263. https://doi.org/10.1016/bs.vh.2018.07.001

Martinerie, L., Munier, M., Le Menuet, D., Meduri, G., Viengchareun, S., Lombès, M., 2013. The mineralocorticoid signaling pathway throughout development: expression, regulation and pathophysiological implications. Biochimie 95, 148-157. https://doi.org/10.1016/j.biochi.2012.09.030

Martinerie, L., Pussard, E., Foix-L'Hélias, L., Petit, F., Cosson, C., Boileau, P., Lombès, M., 2009a. Physiological partial aldosterone resistance in human newborns. Pediatr. Res. 66, 323-328. https://doi.org/10.1203/PDR.0b013e3181b1bbec

Martinerie, L., Pussard, E., Yousef, N., Cosson, C., Lema, I., Husseini, K., Mur, S., Lombès, M., Boileau, P., 2015. Aldosterone-Signaling Defect Exacerbates Sodium Wasting in Very Preterm Neonates: The Premaldo Study. J Clin Endocrinol Metab 100, 4074-4081. https://doi.org/10.1210/jc.2015-2272

Martinerie, L., Viengchareun, S., Delezoide, A.-L., Jaubert, F., Sinico, M., Prevot, S., Boileau, P., Meduri, G., Lombès, M., 2009b. Low renal mineralocorticoid receptor expression at birth contributes to partial aldosterone resistance in neonates. Endocrinology 150, 4414-4424. https://doi.org/10.1210/en.2008-1498

Marver, D., Stewart, J., Funder, J.W., Feldman, D., Edelman, I.S., 1974. Renal aldosterone receptors: studies with $(3 \mathrm{H})$ aldosterone and the anti-mineralocorticoid (3H)spirolactone (SC-26304). Proc. Natl. Acad. Sci. U.S.A. 71, 1431-1435. 
Mesiano, S., Jaffe, R.B., 1997a. Developmental and functional biology of the primate fetal adrenal cortex. Endocr Rev 18, 378-403. https://doi.org/10.1210/edrv.18.3.0304

Mesiano, S., Jaffe, R.B., 1997b. Role of growth factors in the developmental regulation of the human fetal adrenal cortex. Steroids 62, 62-72. https://doi.org/10.1016/s0039-128x(96)00161-4

Miao, H., Yu, Z., Lu, L., Zhu, H., Auchus, R.J., Liu, J., Jiang, J., Pan, H., Gong, F., Chen, S., Lu, Z., 2019. Analysis of novel heterozygous mutations in the CYP11B2 gene causing congenital aldosterone synthase deficiency and literature review. Steroids 150, 108448. https://doi.org/10.1016/j.steroids.2019.108448

Milano, E.G., Accordi, F., 1986. Evolutionary trends in adrenal gland of anurans and urodeles. J. Morphol. 189, 249-259. https://doi.org/10.1002/jmor.1051890304

Miller, W.L., Auchus, R.J., 2011. The molecular biology, biochemistry, and physiology of human steroidogenesis and its disorders. Endocr Rev 32, 81-151. https://doi.org/10.1210/er.2010-0013

Mirshahi, M., Mirshahi, A., Sedighian, R., Hecquet, C., Faure, J.P., Agarwal, M.K., 1997. Immunochemical demonstration of the mineralocorticoid receptor in ocular tissues. Neuroendocrinology 65, 70-78.

Miyata, K., Rahman, M., Shokoji, T., Nagai, Y., Zhang, G.-X., Sun, G.-P., Kimura, S., Yukimura, T., Kiyomoto, H., Kohno, M., Abe, Y., Nishiyama, A., 2005. Aldosterone stimulates reactive oxygen species production through activation of NADPH oxidase in rat mesangial cells. J. Am. Soc. Nephrol. 16, 2906-2912. https://doi.org/10.1681/ASN.2005040390

Morrison, N., Harrap, S.B., Arriza, J.L., Boyd, E., Connor, J.M., 1990. Regional chromosomal assignment of the human mineralocorticoid receptor gene to 4q31.1. Hum. Genet. 85, 130-132.

Naccache, A., Louiset, E., Duparc, C., Laquerrière, A., Patrier, S., Renouf, S., Gomez-Sanchez, C.E., Mukai, K., Lefebvre, H., Castanet, M., 2016. Temporal and spatial distribution of mast cells and steroidogenic enzymes in the human fetal adrenal. Mol Cell Endocrinol 434, 69-80. https://doi.org/10.1016/j.mce.2016.06.015

Nakamura, Y., Yamazaki, Y., Konosu-Fukaya, S., Ise, K., Satoh, F., Sasano, H., 2015. Aldosterone biosynthesis in the human adrenal cortex and associated disorders. J Steroid Biochem Mol Biol 153, 57-62. https://doi.org/10.1016/j.jsbmb.2015.05.008

Narasaka, T., Suzuki, T., Moriya, T., Sasano, H., 2001. Temporal and spatial distribution of corticosteroidogenic enzymes immunoreactivity in developing human adrenal. Mol Cell Endocrinol 174, 111-120. https://doi.org/10.1016/s0303-7207(00)00445-7

Nevoux, J., Viengchareun, S., Lema, I., Lecoq, A.-L., Ferrary, E., Lombès, M., 2015. Glucocorticoids stimulate endolymphatic water reabsorption in inner ear through aquaporin 3 regulation. Pflugers Arch. 467, 1931-1943. https://doi.org/10.1007/s00424-014-1629-5

Nishiyama, A., Yao, L., Fan, Y., Kyaw, M., Kataoka, N., Hashimoto, K., Nagai, Y., Nakamura, E., Yoshizumi, M., Shokoji, T., Kimura, S., Kiyomoto, H., Tsujioka, K., Kohno, M., Tamaki, T., Kajiya, F., Abe, Y., 2005. Involvement of aldosterone and mineralocorticoid receptors in rat mesangial cell proliferation and deformability. Hypertension 45, 710-716. https://doi.org/10.1161/01.HYP.0000154681.38944.9a

Norris, D., Carr, J., 2013. , in: Vertebrate Endocrinology (Fifth Edition). Academic press, pp. 291-315. Ouvrard-Pascaud, A., Sainte-Marie, Y., Bénitah, J.-P., Perrier, R., Soukaseum, C., Nguyen Dinh Cat, A., Royer, A., Le Quang, K., Charpentier, F., Demolombe, S., Mechta-Grigoriou, F., Beggah, A.T., Maison-Blanche, P., Oblin, M.-E., Delcayre, C., Fishman, G.I., Farman, N., Escoubet, B., Jaisser, F., 2005. Conditional mineralocorticoid receptor expression in the heart leads to lifethreatening arrhythmias. Circulation 3025-3033. https://doi.org/10.1161/CIRCULATIONAHA.104.503706

Ozbaki-Yagan, N., Liu, X., Bodnar, A.J., Ho, J., Butterworth, M.B., 2020. Aldosterone-induced microRNAs act as feedback regulators of mineralocorticoid receptor signaling in kidney epithelia. FASEB J 34, 11714-11728. https://doi.org/10.1096/fj.201902254RR

Palmer, L.G., Schnermann, J., 2015. Integrated Control of Na Transport along the Nephron. CJASN 10, 676-687. https://doi.org/10.2215/CJN.12391213

Pavlides, C., McEwen, B.S., 1999. Effects of mineralocorticoid and glucocorticoid receptors on longterm potentiation in the CA3 hippocampal field. Brain Res. 851, 204-214. 
Penfornis, P., Viengchareun, S., Le Menuet, D., Cluzeaud, F., Zennaro, M.C., Lombès, M., 2000. The mineralocorticoid receptor mediates aldosterone-induced differentiation of T37i cells into brown adipocytes. Am. J. Physiol. Endocrinol. Metab. 279, E386-394.

Pippal, J.B., Cheung, C.M.I., Yao, Y.-Z., Brennan, F.E., Fuller, P.J., 2011. Characterization of the zebrafish (Danio rerio) mineralocorticoid receptor. Mol Cell Endocrinol 332, 58-66. https://doi.org/10.1016/j.mce.2010.09.014

Pitovski, D.Z., Drescher, M.J., Drescher, D.G., 1993. High affinity aldosterone binding sites (type I receptors) in the mammalian inner ear. Hear. Res. 69, 10-14.

Pressley, L., Funder, J.W., 1975. Glucocorticoid and mineralocorticoid receptors in gut mucosa. Endocrinology 97, 588-596. https://doi.org/10.1210/endo-97-3-588

Prunet, P., Sturm, A., Milla, S., 2006. Multiple corticosteroid receptors in fish: from old ideas to new concepts. Gen Comp Endocrinol 147, 17-23. https://doi.org/10.1016/j.ygcen.2006.01.015

Pussard, E., Travers, S., Bouvattier, C., Xue, Q.-Y., Cosson, C., Viengchareun, S., Martinerie, L., Lombès, M., 2020. Urinary steroidomic profiles by LC-MS/MS to monitor classic 21Hydroxylase deficiency. J Steroid Biochem Mol Biol 198, 105553. https://doi.org/10.1016/j.jsbmb.2019.105553

Rafestin-Oblin, M.E., Couette, B., Radanyi, C., Lombes, M., Baulieu, E.E., 1989. Mineralocorticosteroid receptor of the chick intestine. Oligomeric structure and transformation. J Biol Chem 264, 9304-9309.

Rickard, A.J., Morgan, J., Tesch, G., Funder, J.W., Fuller, P.J., Young, M.J., 2009. Deletion of mineralocorticoid receptors from macrophages protects against deoxycorticosterone/saltinduced cardiac fibrosis and increased blood pressure. Hypertension 54, 537-543. https://doi.org/10.1161/HYPERTENSIONAHA.109.131110

Robertson, S., Diver, L.A., Alvarez-Madrazo, S., Livie, C., Ejaz, A., Fraser, R., Connell, J.M., MacKenzie, S.M., Davies, E., 2017. Regulation of Corticosteroidogenic Genes by MicroRNAs. Int J Endocrinol 2017, 2021903. https://doi.org/10.1155/2017/2021903

Romagni, P., Rossi, F., Guerrini, L., Quirini, C., Santiemma, V., 2003. Aldosterone induces contraction of the resistance arteries in man. Atherosclerosis 166, 345-349. https://doi.org/10.1016/s00219150(02)00363-5

Rondinone, C.M., Rodbard, D., Baker, M.E., 1993. Aldosterone stimulated differentiation of mouse 3T3-L1 cells into adipocytes. Endocrinology 132, 2421-2426. https://doi.org/10.1210/endo.132.6.8504747

Ronzaud, C., Loffing, J., Gretz, N., Schütz, G., Berger, S., 2011. Inducible renal principal cell-specific mineralocorticoid receptor gene inactivation in mice. Am J Physiol Renal Physiol 300, F756760. https://doi.org/10.1152/ajprenal.00728.2009

Rossier, B.C., 2016. Osmoregulation during Long-Term Fasting in Lungfish and Elephant Seal: Old and New Lessons for the Nephrologist. Nephron 134, 5-9. https://doi.org/10.1159/000444307

Sainte Marie, Y., Toulon, A., Paus, R., Maubec, E., Cherfa, A., Grossin, M., Descamps, V., Clemessy, M., Gasc, J.-M., Peuchmaur, M., Glick, A., Farman, N., Jaisser, F., 2007. Targeted skin overexpression of the mineralocorticoid receptor in mice causes epidermal atrophy, premature skin barrier formation, eye abnormalities, and alopecia. Am J Pathol 171, 846-860. https://doi.org/10.2353/ajpath.2007.060991

Sakamoto, T., Hyodo, S., Takagi, W., 2018. A possible principal function of corticosteroid signaling that is conserved in vertebrate evolution: Lessons from receptor-knockout small fish. J Steroid Biochem Mol Biol 184, 57-61. https://doi.org/10.1016/j.jsbmb.2018.02.011

Scholl, U.I., Goh, G., Stölting, G., de Oliveira, R.C., Choi, M., Overton, J.D., Fonseca, A.L., Korah, R., Starker, L.F., Kunstman, J.W., Prasad, M.L., Hartung, E.A., Mauras, N., Benson, M.R., Brady, T., Shapiro, J.R., Loring, E., Nelson-Williams, C., Libutti, S.K., Mane, S., Hellman, P., Westin, G., Åkerström, G., Björklund, P., Carling, T., Fahlke, C., Hidalgo, P., Lifton, R.P., 2013. Somatic and germline CACNA1D calcium channel mutations in aldosterone-producing adenomas and primary aldosteronism. Nat Genet 45, 1050-1054. https://doi.org/10.1038/ng.2695

Scholl, U.I., Stölting, G., Nelson-Williams, C., Vichot, A.A., Choi, M., Loring, E., Prasad, M.L., Goh, G., Carling, T., Juhlin, C.C., Quack, I., Rump, L.C., Thiel, A., Lande, M., Frazier, B.G., Rasoulpour, M., Bowlin, D.L., Sethna, C.B., Trachtman, H., Fahlke, C., Lifton, R.P., 2015. 
Recurrent gain of function mutation in calcium channel CACNA1H causes early-onset hypertension with primary aldosteronism. Elife 4, e06315. https://doi.org/10.7554/eLife.06315

Scholl, U.I., Stölting, G., Schewe, J., Thiel, A., Tan, H., Nelson-Williams, C., Vichot, A.A., Jin, S.C., Loring, E., Untiet, V., Yoo, T., Choi, J., Xu, S., Wu, A., Kirchner, M., Mertins, P., Rump, L.C., Onder, A.M., Gamble, C., McKenney, D., Lash, R.W., Jones, D.P., Chune, G., Gagliardi, P., Choi, M., Gordon, R., Stowasser, M., Fahlke, C., Lifton, R.P., 2018. CLCN2 chloride channel mutations in familial hyperaldosteronism type II. Nat Genet 50, 349-354. https://doi.org/10.1038/s41588-018-0048-5

Schwartz, B., Wysocki, A., 1997. Mineralocorticoid receptors in the rabbit iris-ciliary body. Ophthalmic Res. 29, 42-47.

Seccia, T.M., Caroccia, B., Gomez-Sanchez, E.P., Gomez-Sanchez, C.E., Rossi, G.P., 2018. The Biology of Normal Zona Glomerulosa and Aldosterone-Producing Adenoma: Pathological Implications. Endocr Rev 39, 1029-1056. https://doi.org/10.1210/er.2018-00060

Shibata, S., Nagase, M., Yoshida, S., Kawachi, H., Fujita, T., 2007. Podocyte as the target for aldosterone: roles of oxidative stress and Sgk1. Hypertension 49, 355-364. https://doi.org/10.1161/01.HYP.0000255636.11931.a2

Sturm, A., Bury, N., Dengreville, L., Fagart, J., Flouriot, G., Rafestin-Oblin, M.E., Prunet, P., 2005. 11deoxycorticosterone is a potent agonist of the rainbow trout (Oncorhynchus mykiss) mineralocorticoid receptor. Endocrinology 146, 47-55. https://doi.org/10.1210/en.2004-0128

Suarez-Rivera, M., Bonilla-Felix, M., 2014. Fluid and Electrolyte Disorders in the Newborn: Sodium and Potassium. CPR 10, 115-122. https://doi.org/10.2174/157339631002140513102053

Suntharalingham, J.P., Buonocore, F., Duncan, A.J., Achermann, J.C., 2015. DAX-1 (NR0B1) and steroidogenic factor-1 (SF-1, NR5A1) in human disease. Best Pract Res Clin Endocrinol Metab 29, 607-619. https://doi.org/10.1016/j.beem.2015.07.004

Teixeira, M., Viengchareun, S., Butlen, D., Ferreira, C., Cluzeaud, F., Blot-Chabaud, M., Lombès, M., Ferrary, E., 2006. Functional IsK/KvLQT1 potassium channel in a new corticosteroid-sensitive cell line derived from the inner ear. J. Biol. Chem. 281, 10496-10507. https://doi.org/10.1074/jbc.M512254200

Travers, S., Martinerie, L., Boileau, P., Lombès, M., Pussard, E., 2018. Alterations of adrenal steroidomic profiles in preterm infants at birth. Arch. Dis. Child. Fetal Neonatal Ed. 103, F143F151. https://doi.org/10.1136/archdischild-2016-312457

Travers, S., Martinerie, L., Bouvattier, C., Boileau, P., Lombès, M., Pussard, E., 2017. Multiplexed steroid profiling of gluco- and mineralocorticoids pathways using a liquid chromatography tandem mass spectrometry method. J Steroid Biochem Mol Biol 165, 202-211. https://doi.org/10.1016/j.jsbmb.2016.06.005

Underwood, M.A., Gilbert, W.M., Sherman, M.P., 2005. Amniotic fluid: not just fetal urine anymore. J Perinatol 25, 341-348. https://doi.org/10.1038/sj.jp.7211290

van den Anker, J.N., de Groot, R., Broerse, H.M., Sauer, P.J., van der Heijden, B.J., Hop, W.C., Lindemans, J., 1995. Assessment of glomerular filtration rate in preterm infants by serum creatinine: comparison with inulin clearance. Pediatrics 96, 1156-1158.

Van Eekelen, J.A., Jiang, W., De Kloet, E.R., Bohn, M.C., 1988. Distribution of the mineralocorticoid and the glucocorticoid receptor mRNAs in the rat hippocampus. J. Neurosci. Res. 21, 88-94. https://doi.org/10.1002/jnr.490210113

van Weert, L.T.C.M., Buurstede, J.C., Sips, H.C.M., Mol, I.M., Puri, T., Damsteegt, R., Roozendaal, B., Sarabdjitsingh, R.A., Meijer, O.C., 2019. Mechanistic Insights in NeuroD Potentiation of Mineralocorticoid Receptor Signaling. Int J Mol Sci 20. https://doi.org/10.3390/ijms20071575

Viengchareun, S., Kamenicky, P., Teixeira, M., Butlen, D., Meduri, G., Blanchard-Gutton, N., Kurschat, C., Lanel, A., Martinerie, L., Sztal-Mazer, S., Blot-Chabaud, M., Ferrary, E., Cherradi, N., Lombès, M., 2009. Osmotic stress regulates mineralocorticoid receptor expression in a novel aldosterone-sensitive cortical collecting duct cell line. Mol. Endocrinol. 23, 1948-1962. https://doi.org/10.1210/me.2009-0095

Viengchareun, S., Le Menuet, D., Martinerie, L., Munier, M., Pascual-Le Tallec, L., Lombès, M., 2007. The mineralocorticoid receptor: insights into its molecular and (patho)physiological biology. Nucl Recept Signal 5, e012. https://doi.org/10.1621/nrs.05012 
Viengchareun, S., Lema, I., Lamribet, K., Keo, V., Blanchard, A., Cherradi, N., Lombès, M., 2014. Hypertonicity compromises renal mineralocorticoid receptor signaling through Tis $11 \mathrm{~b}$ mediated post-transcriptional control. J. Am. Soc. Nephrol. 25, 2213-2221. https://doi.org/10.1681/ASN.2013091023

Wils, J., Duparc, C., Cailleux, A.-F., Lopez, A.-G., Guiheneuf, C., Boutelet, I., Boyer, H.-G., Dubessy, C., Cherifi, S., Cauliez, B., Gobet, F., Defortescu, G., Ménard, J.-F., Louiset, E., Lefebvre, H., 2020. The neuropeptide substance $P$ regulates aldosterone secretion in human adrenals. Nat Commun 11, 2673. https://doi.org/10.1038/s41467-020-16470-8

Wotus, C., Levay-Young, B.K., Rogers, L.M., Gomez-Sanchez, C.E., Engeland, W.C., 1998. Development of adrenal zonation in fetal rats defined by expression of aldosterone synthase and 11beta-hydroxylase. $\quad$ Endocrinology $139, \quad 4397-4403$. https://doi.org/10.1210/endo.139.10.6230

Zennaro, M.-C., Boulkroun, S., Fernandes-Rosa, F., 2017. Genetic Causes of Functional Adrenocortical Adenomas. Endocr Rev 38, 516-537. https://doi.org/10.1210/er.2017-00189

Zennaro, M.-C., Boulkroun, S., Fernandes-Rosa, F.L., 2020. Pathogenesis and treatment of primary aldosteronism. Nat Rev Endocrinol 16, 578-589. https://doi.org/10.1038/s41574-020-0382-4

Zennaro, M.-C., Fernandes-Rosa, F., 2017. 30 YEARS OF THE MINERALOCORTICOID RECEPTOR: Mineralocorticoid receptor mutations. J. Endocrinol. 234, T93-T106. https://doi.org/10.1530/JOE-17-0089

Zennaro, M.C., Keightley, M.C., Kotelevtsev, Y., Conway, G.S., Soubrier, F., Fuller, P.J., 1995. Human mineralocorticoid receptor genomic structure and identification of expressed isoforms. J. Biol. Chem. 270, 21016-21020.

Zennaro, M.C., Le Menuet, D., Lombès, M., 1996. Characterization of the human mineralocorticoid receptor gene 5'-regulatory region: evidence for differential hormonal regulation of two alternative promoters via nonclassical mechanisms. Mol. Endocrinol. 10, 1549-1560. https://doi.org/10.1210/mend.10.12.8961265

Zennaro, M.C., Le Menuet, D., Viengchareun, S., Walker, F., Ricquier, D., Lombès, M., 1998. Hibernoma development in transgenic mice identifies brown adipose tissue as a novel target of aldosterone action. J. Clin. Invest. 101, 1254-1260. https://doi.org/10.1172/JCI1915

Zennaro, M.C., Souque, A., Viengchareun, S., Poisson, E., Lombès, M., 2001. A new human MR splice variant is a ligand-independent transactivator modulating corticosteroid action. Mol. Endocrinol. 15, 1586-1598. https://doi.org/10.1210/mend.15.9.0689

Zhang, J., Simisky, J., Tsai, F.T.F., Geller, D.S., 2005. A critical role of helix 3-helix 5 interaction in steroid hormone receptor function. Proc Natl Acad Sci U S A 102, 2707-2712. https://doi.org/10.1073/pnas.0409663102

Zhao, M., Célérier, I., Bousquet, E., Jeanny, J.-C., Jonet, L., Savoldelli, M., Offret, O., Curan, A., Farman, N., Jaisser, F., Behar-Cohen, F., 2012. Mineralocorticoid receptor is involved in rat and human ocular chorioretinopathy. J Clin Invest 122, 2672-2679. https://doi.org/10.1172/JCI61427

Zoetis, T., Hurtt, M.E., 2003. Species comparison of anatomical and functional renal development. Birth Defect Res B 68, 111-120. https://doi.org/10.1002/bdrb.10013 


\section{Figures Legends:}

Figure 1: Physiological regulation of aldosterone production in steroidogenic cells of the Zona Glomerulosa (ZG).

Binding of AngII to AT1R leads the depolarization of the cell membrane that inhibits potassium channels and the $\mathrm{Na}^{+}, \mathrm{K}^{+}$-ATPase and subsequently triggers an influx of extracellular $\mathrm{Ca}^{2+}$ and a release of $\mathrm{Ca}^{2+}$ from the endoplasmic reticulum, that activates calcium/calmodulin-dependent protein kinases (CaMKs). Then, CaMKs increase expression and phosphorylation of transcription factors such as Nurr1 and CREB1 thus stimulating expression of the CYP11B2 gene, which encodes the aldosterone synthase, the enzyme that catalyzes the last steps of aldosterone biosynthesis.

AngII: Angiotensin II; AT1R: Angiotensin 1 Receptor; TASK 1/3: potassium channels.

Figure 2: Model of mineralocorticoid signaling in the distal polarized tubular cell of the kidney. Aldosterone binds to its intracytoplasmic receptor. The aldosterone-MR complex is translocated to the nucleus where it binds DNA in the form of homo- or heterodimers and initiates the transcription of specific target genes. In the kidney, most of these target genes are involved in the regulation of sodium reabsorption from primary urine (apical compartment) to the interstitium (basolateral compartment). MR: Mineralocorticoid Receptor, MRE: Mineralocorticoid Response Element. Target genes of the mineralocorticoid pathway: $\mathrm{Na}^{+}, \mathrm{K}^{+}-$ ATPase: $\mathrm{Na}^{+}, \mathrm{K}^{+}$-ATPase pump, Gilz: Glucocorticoid-induced leucine zipper, ENaC: Epithelial $\mathrm{Na}^{+}$Channel, Sgk1: Serum and Glucocorticoid-Regulated kinase 1, Nedd4-2 : Ubiquitin Ligase of the Nedd4 family, KS-WNK1: With No lysine K kinase, NDRG2 : N-myc Down-Regulated Gene 2, PER 1: clock gene period 1. TM: Transcriptional Machinery. 
Figure 3: Expression of corticosteroid receptors and their ligands throughout evolution. Adapted from and courtesy of P. Prunet, INRA, Rennes, France

CR: ancestral corticosteroid receptor, GR: Glucocorticoid Receptor, MR: Mineralocorticoid Receptor, F: Cortisol, DOC: Deoxycorticosterone, $1 \alpha-B$ : 1 alpha-corticosterone, 11ßHSD2: 11 beta-hydroxysteroid dehydrogenase type 2 (adapted from and courtesy of P. Prunet, INRA Rennes, France).

Figure 4: Mineralocorticoid receptor expression profile during development in mice and humans. MR: Mineralocorticoid receptor. D0: Day of birth.GW: week of gestation. E16-18: $16^{\text {th }}$ to $18^{\text {th }}$ day of gestation. 


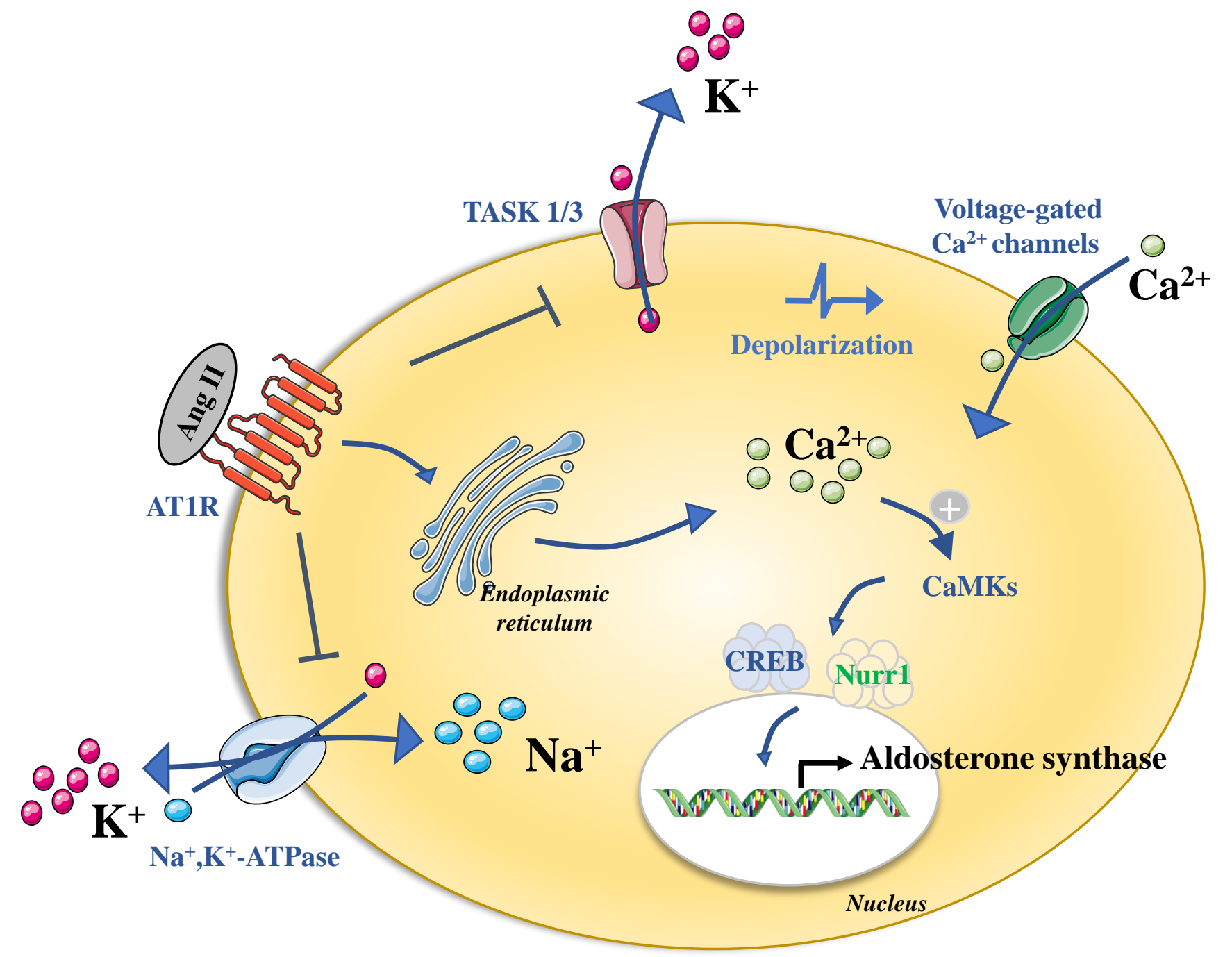

Figure 1 


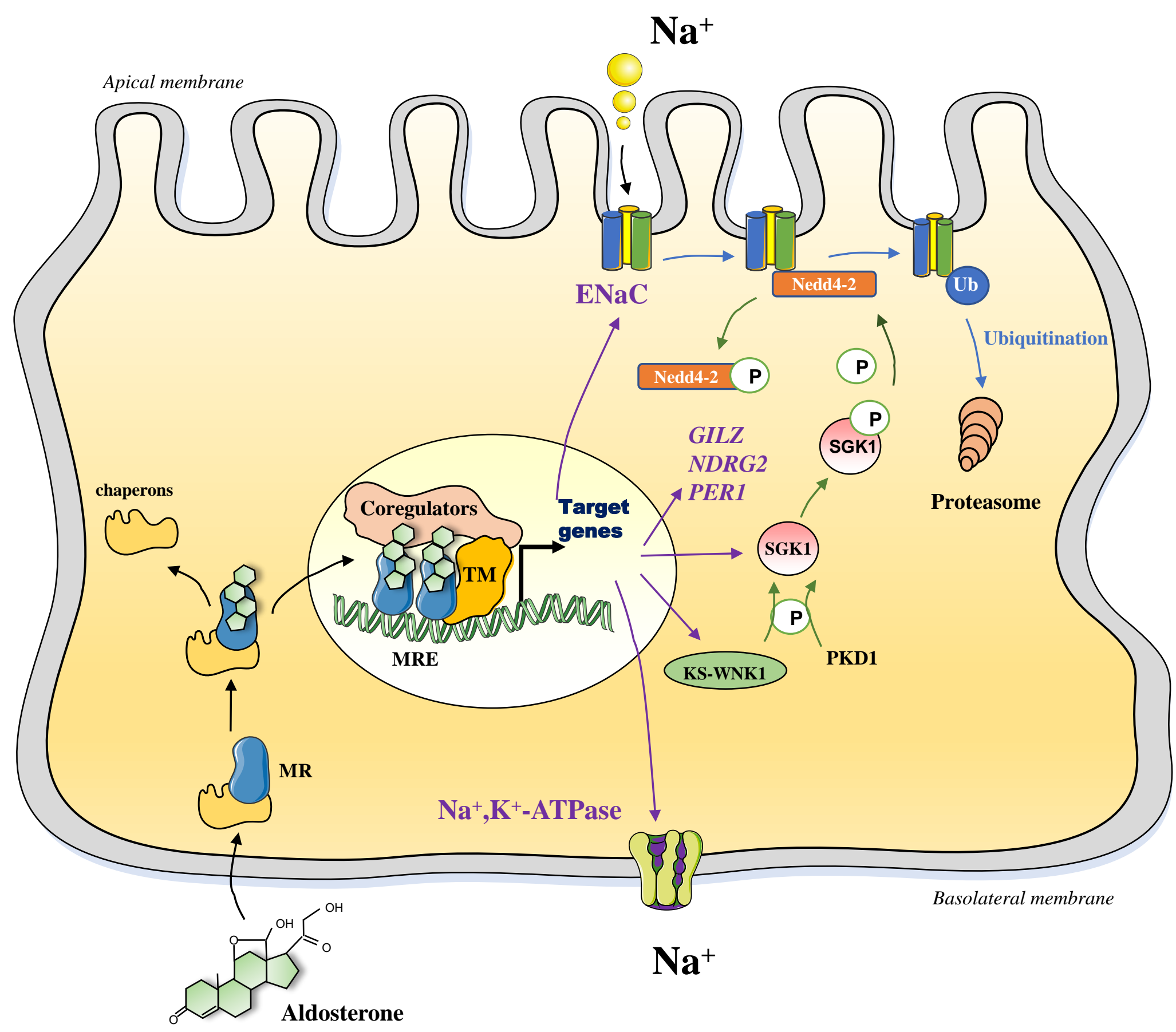




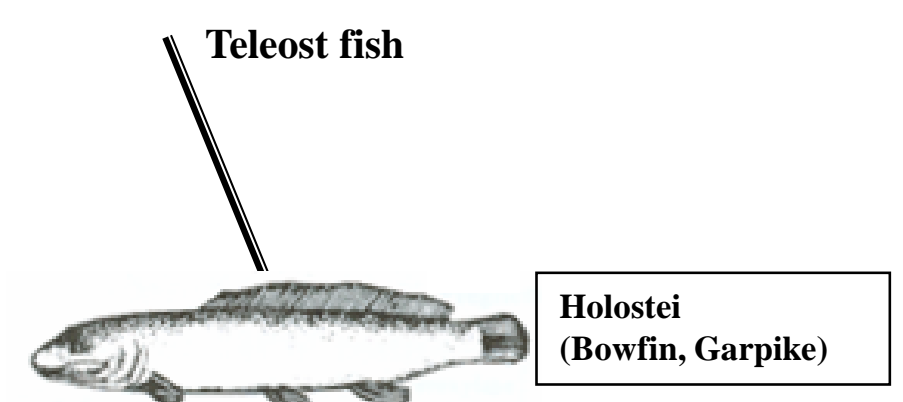

(Bowfin, Garpike)

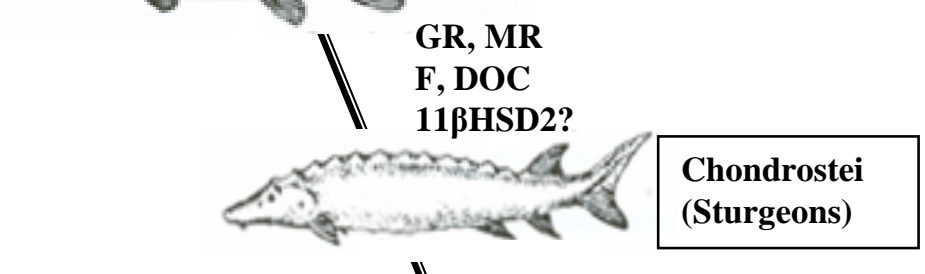

GR, MR
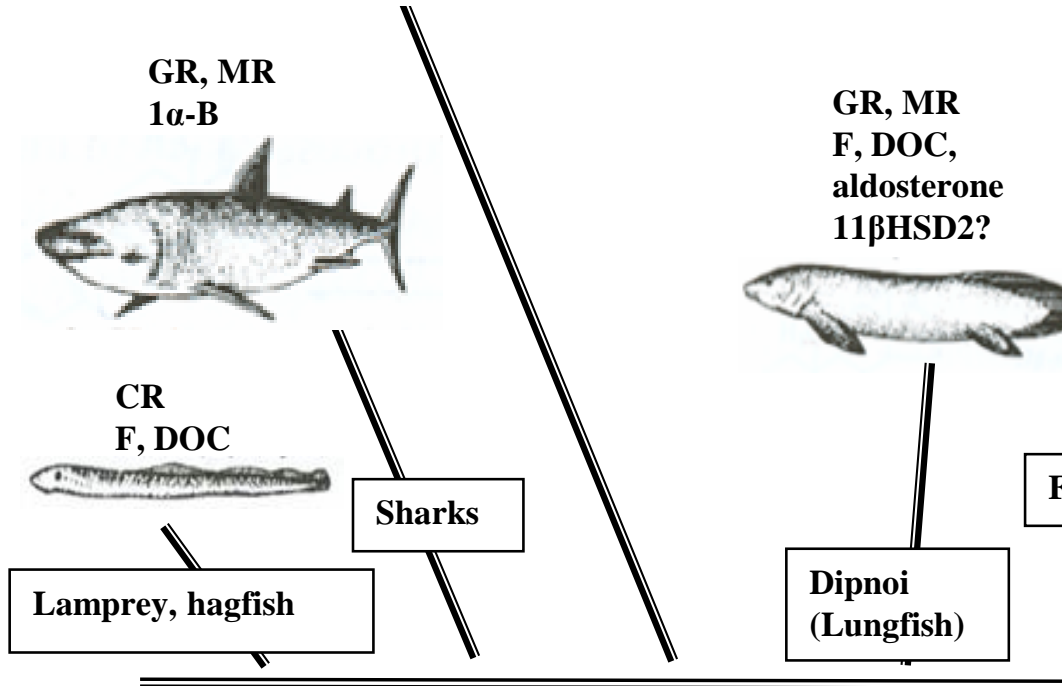

F, aldosterone

11ßHSD2

$\overline{--1}$

\section{Vertebrate}

(

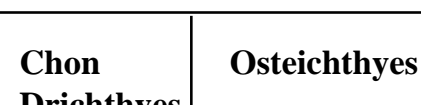

(Lungfish)

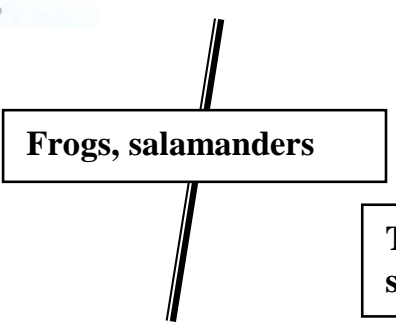

GR, MR

$F$, aldosterone

11ßHSD2

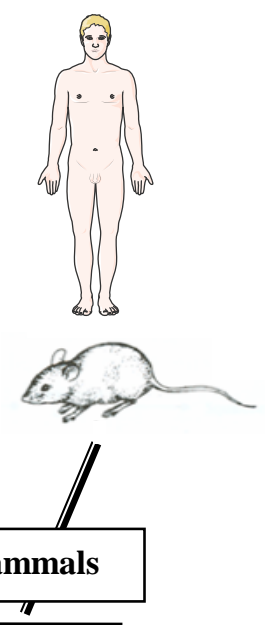

Turtles, lizards, snakes, crocodiles
GR, MR

GR, MR

$\mathrm{B}$, aldosterone

11ßHSD2
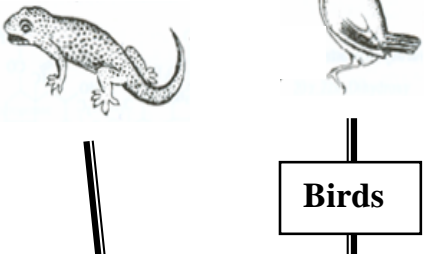

11ßHSD2

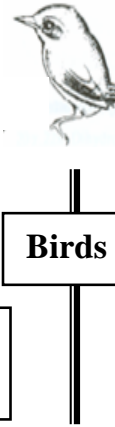

Mammals

ancestors

Agnatha

Drichthyes

Amphibia

Reptilia

Aves

Mammalia

\section{Figure 3}




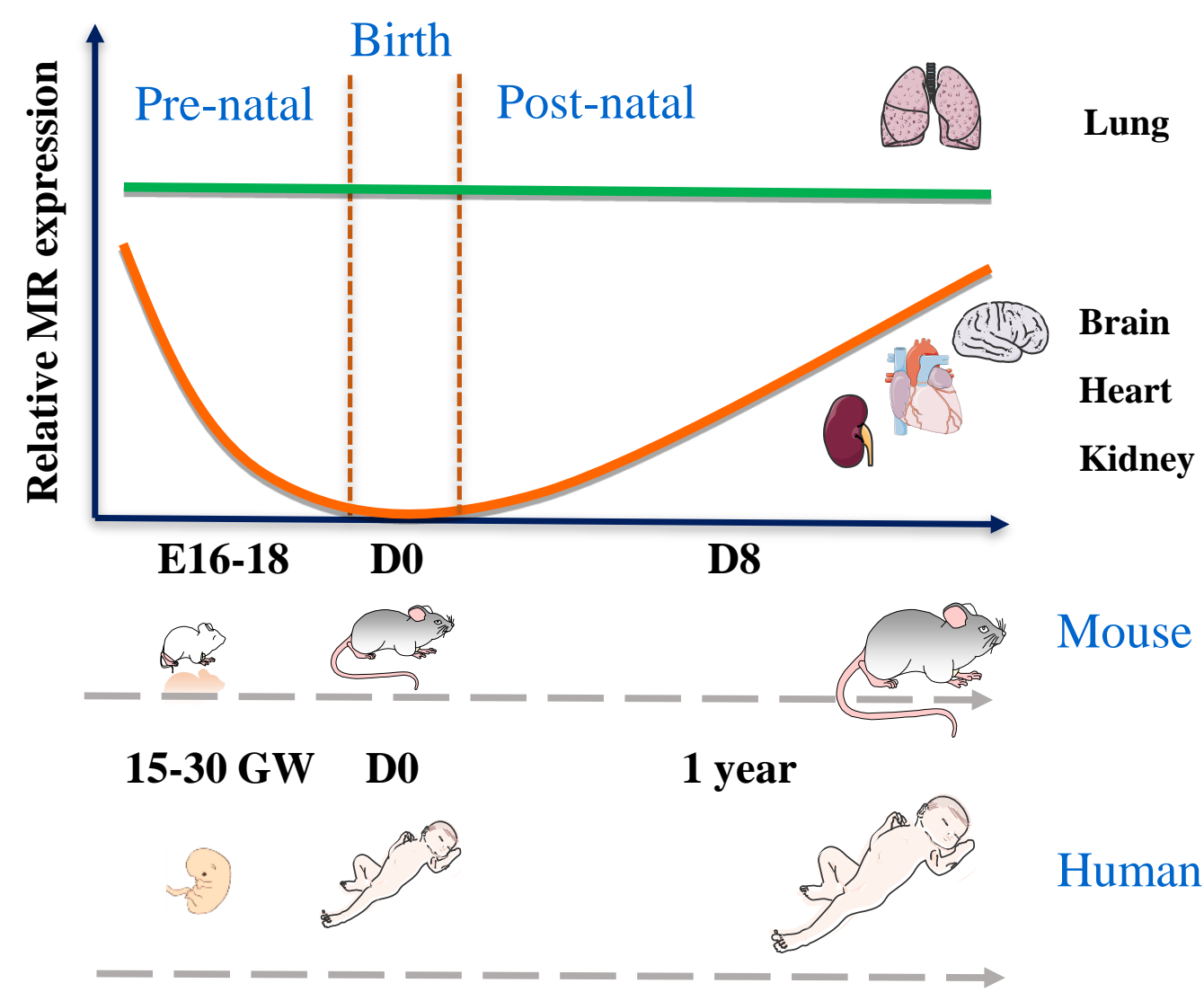

Figure 4 